\title{
The ANZUS Treaty: A Reinterpretation of U.S. Diplomacy in the Southwest Pacific
}

Thomas K. Robb and David James Gill

The Australia, New Zealand, United States (ANZUS) Security Treaty celebrated its sixtieth anniversary in $2011 .{ }^{1}$ The formal defense pact, which was signed on September 1, 1951 and came into being on April 29, 1952, bound together Australia, New Zealand and the United States. The ANZUS Treaty recognized that an armed attack on any one of the signatories endangered the peace and safety of the others. Each national government consequently pledged to maintain and develop individual and collective capabilities to resist attack. ${ }^{2}$ Although the course of events remains uncontested, the origin of the Treaty continues to generate considerable interest among historians. There exist a wide variety of interpretations and perspectives about the aims of the participants and the nature of negotiations. ${ }^{3}$

Many scholars, as well as most of the individuals involved in drafting the agreement, stress the importance of Australian diplomacy. U.S. Secretary of State Dean Acheson suggested that America cooperated because Australia required such a security pact in order to support U.S. plans for a lenient Japanese peace treaty. ${ }^{4}$ Robert Beisner, Acheson's biographer, broadly agrees with this assessment. The pact, Beisner explains, was one of the "grudgingly paid tolls on the turnpike to the San Francisco peace conference." ${ }^{5}$ At the heart of these interpretations, then, is the skill of Australian officials, managing to convince a reluctant superpower to commit to a tripartite security pact. $^{6}$ Unsurprisingly, other scholars have challenged this interpretation, emphasizing that the United States was hardly a reluctant convert to Southwestern Pacific security. A rising Communist threat throughout Asia, evidenced by the onset of the Korean War, encouraged the United States to engage in a number of military pacts within the Pacific region, with ANZUS being just one such example. ${ }^{7}$

Much of the disagreement stems from historians' focus on decision-making within only one country. Looking to one, rather than all, of the major actors involved in the negotiations distorts analysis of diplomacy in the region. In order to understand the origins of the ANZUS Treaty, a multinational approach is essential. In addition, existing accounts of events, wherever positioned within the historiography, tend to rely on narrowly focused explanations for the motivations of the key participants. The ambitions of America, Australia and New Zealand in the Pacific region were far 
more complex than many historians have suggested. Drawing together source material from both sides of the Pacific and the Atlantic, this article offers four major contributions to the historiography.

First, the origins of the Treaty reflected a compromise between the United States, Australia and New Zealand. Growing Cold War concerns drove America's commitment to international cooperation. Although the antipodean powers obtained a security pact, the U.S. managed to secure a non-punitive Japanese Peace Treaty in exchange, thereby harnessing the country's economic and industrial potential in the containment of Communism. This quid pro quo helped to overcome initial resistance in Washington to the idea of creating any such formal agreement. The ANZUS Treaty was limited in scope, however, consequently disappointing Australian and New Zealand ambitions for a more comprehensive security alliance. The agreement also ensured that the antipodean powers remained militarily committed to the Middle East and Mediterranean thereby complementing America's wider Cold War strategy.

Second, existing accounts concerning the origins of the U.S. commitment to Southwestern Pacific security largely overlook the economic rationale underlying decision-making. ${ }^{8}$ Washington sought regional cooperation to ensure the swift revival of Japan, which played an increasingly important role in opposing Communism in Asia following the outbreak of the Korean War in 1950. Providing security commitments to Australia and New Zealand would help to lessen antipodean fears about the risks of increased economic cooperation with Japan. Furthermore, closer U.S.-antipodean relations would place America in a stronger position from which to discuss discriminatory trading policies in the region, known as Imperial Preference, that could inhibit economic revival or undermine longer-term stability. None of this is to suggest that America simply sought to establish a profitable economic empire but rather that economic and military factors were interdependent. ${ }^{9}$

Third, the historiography has downplayed the importance of the Anglo-American dynamic of the ANZUS Treaty. As American alliance building occurred throughout the region, the transatlantic relationship suffered. Existing accounts of Anglo-American relations routinely downplay or ignore American attempts to ensure British exclusion from the ANZUS Treaty. ${ }^{10}$ The Eisenhower administration's eventual recourse to vigorous diplomacy amongst the Treaty members ultimately ensured that ANZUS did not expand beyond a tripartite agreement. These insights cast much needed 
light on the weakening of British influence in the region. Such events also complement much of the "declinist" literature of the post-war period, revealing the rejection of British security provision and the erosion of traditional economic relations in the Pacific. ${ }^{11}$

Fourth, the historiography continues to simplify how ideas about race and imperialism influenced the decision making process. Bigotry, as well as concerns about prejudice, has influenced American actions on the global stage. ${ }^{12}$ Yet the idea of race was more than merely a motivation for, or deterrent to, certain foreign policy choices in the Pacific. U.S. policymakers sometimes used ideas about race as a tool for the advancement of their own goals. Drawing attention to the divisions between Anglo-Saxon and Asian peoples legitimized an ANZUS Treaty on a tripartite basis. American claims that British membership would create an image of a "White Man's Club" throughout the Pacific, and thus damage relations with the "non-white" powers in the region, helped to excuse continued British exclusion, avoided problematic calls for the creation of a broader alliance system in Asia, and obscured more important and self-interested motivations. Public claims about the importance of racial concerns, albeit exaggerated or sometimes disingenuous, thus helped to sustain the ANZUS Treaty on a tripartite basis preferable to U.S. interests. ${ }^{13}$ In addition, some Australian and New Zealand policy-makers sought to avoid extending membership of ANZUS to Asian powers for reasons that were in part motivated by racial considerations. ${ }^{14}$

Taken together, these four contributions make a broader point about the geographical compartmentalization of U.S. foreign policy. In the Pacific, Australia, New Zealand, and the United Kingdom enjoyed different experiences of American diplomacy. The antipodean governments managed to obtain their long sought after security pact. The United States' most important European ally, however, saw its interests routinely marginalized. Yet economic and military cooperation with the United Kingdom continued in other parts of the world. The "special relationship" evidently did not always apply on a global basis; Washington often viewed it as relevant only in a regional sense. British weakness, alongside the growing reliance of Australia and New Zealand on American power, allowed successive U.S. administrations to pursue American diplomacy in the Southwest Pacific largely as they saw fit. 
This article divides into four sections. The first section contextualizes the ANZUS Treaty, comparing and contrasting American, Australian, New Zealand and British post-war ambitions. Despite many similarities, the four countries sought different military and economic objectives in the Pacific region. Diplomacy was thus more discordant than generally assumed. The second section explains the emergence of the ANZUS Treaty. As the Cold War intensified, Washington sought to create a lenient Japanese peace treaty, which would end the occupation of Japan and harness its economic and industrial potential in the containment of Communism. The antipodean governments argued instead that a punitive peace treaty was required to prevent a resurgence of Japanese militarism. After considerable deliberation, the ANZUS Treaty emerged as the preferred solution to this diplomatic impasse.

The third section looks at the negotiations surrounding the Treaty. Once the U.S., Australian and New Zealand delegations convened in Canberra in February 1951, discussions about the nature of a Japanese peace settlement and a security pact began in earnest. The resultant agreement benefited all of the participants. Yet, in assessing the terms of the Treaty, no single power obtained all of its objectives. The fourth section explains how the United States managed to maintain a tripartite agreement in the face of sustained opposition from Britain and, to a lesser extent, Australia and New Zealand. The United States continually legitimized British exclusion from ANZUS by claiming that British membership would establish a "White Man's Pact" in the Pacific and would do significant damage to U.S. relations with key Asian allies. Such justifications, however, rarely drove policy. U.S. reluctance to expand ANZUS centered on fears that British membership would lead to a broader Pacific security pact that would extend American commitments in the region and do so at considerable cost.

\section{Pacific Diplomacy}

Despite many similarities, America, Australia and New Zealand, and the United Kingdom sometimes sought different military and economic objectives in the Pacific region in the post-war period. The following three subsections compare and contrast these countries' competing international ambitions, which help to shed light on the subsequent course of U.S. diplomacy. 


\section{The United States of America}

Following the end of the Second World War, Australia assumed a growing importance in American thinking. An internal policy document from the State Department reveals that it was a "fundamental" objective to "maintain and strengthen the close ties of friendship between the two countries" established during the Second World War. Australia, the document noted, occupied an "important geographical position" with a people "whose way of life and whose political ideology is similar to our own." 15 The relationship nevertheless suffered some tensions. Under the government of Ben Chifley, the Australians had assumed a role that was sometimes troublesome for U.S. interests especially within the United Nations. ${ }^{16}$ Policy disputes marked relations during 1945-49, and Canberra's insistence of pursing an "unpolarised line in foreign policy" irritated Washington. ${ }^{17}$ Nevertheless, at least in the assessment of the State Department, the Australians could be "generally counted on to vote on our side." ${ }^{18}$ Australia had evidently secured a position of importance to the U.S. government well before the "loss" of China and the onset of the Korean War. Indeed, as the Cold War began to polarize international relations more keenly, the role of such "third actors" was of increasing interest for U.S. policy-makers.

Economic factors, often downplayed by existing accounts, also help to explain this growing interest in cooperation with Australia. The Bretton Woods Agreement of 1944, of which Australia was a signatory, meant that the U.S. dollar functioned as the pivot of the global exchange system. All signatories pegged their currencies to the U.S. dollar on the assumption that a fixed parity system would stabilize international trade and, in turn, temper the violent nature of international relations. ${ }^{19}$ Yet persistent dollar deficits, alongside the continuation of tariff protection, complicated this new economic order. ${ }^{20}$ Australia possessed an adverse balance of dollar payments and was unwilling to forego the trading advantages it enjoyed as a member of the British Commonwealth. ${ }^{21}$ Nevertheless, the State Department recognized the growing economic importance of Australia in the Southeast Asian region and to international trade more broadly. ${ }^{22}$ This argument complements recent research concerning the origins and implementation of the Truman administration's national security objectives as enunciated within NSC-68. The massive rearmament program endorsed by NSC-68 
reflected concerns about ensuring the survival of the nascent global economy, an essential component of post-war U.S. prosperity, as well as containing the Communist threat. ${ }^{23}$

Equally important, interest in Australia reflected broader geostrategic shifts. The stability and reconstruction of Europe was America's primary goal at the end of the Second World War. As relations with the Soviet Union deteriorated, however, the situation in the Pacific became more important. Domestically, there existed a growing fear about the threat of a global Communist conspiracy, which was encouraged by revelations about the extent of Soviet espionage throughout the Western world. The Soviet Union's explosion of an atomic bomb in August 1949, believed by many to reflect the success of Soviet espionage, catalyzed such anxieties and shattered America's atomic monopoly. The subsequent defeat of nationalist forces in China in the following month further encouraged American fears of a global Communist threat. ${ }^{24}$

The ascension of Mao Zedong and the creation of the People's Republic of China (PRC) increased U.S. interest in Asian security. For instance, the Truman administration now began to increase its material support for France in its war inside Indochina because France was now presumed to be fighting a Communist supported enemy and thus preventing further Communist expansion. ${ }^{25}$ The Korean War, deemed by the Truman administration as an act of flagrant Communist aggression, fuelled growing U.S. concerns about the Communist threat. As such, the idea of a broader Pacific security pact became increasingly attractive to U.S. policymakers. ${ }^{26}$ John Foster Dulles, appointed by Truman in 1950 to negotiate a Japanese peace settlement and the subsequent terms of the ANZUS Treaty, would even go as far to suggest that what was required was a "Pacific NATO" to combat the growing menace of Communism throughout the region. ${ }^{27}$

Japan therefore came to assume a position of extreme importance in U.S. strategic planning. Senior U.S. policy-makers concluded that if Japan fell into the possession of the Soviet Union, the Communist bloc would harness its economic and industrial might and threaten American stability and interests throughout the region. ${ }^{28}$ Thus NSC 13/2, delivered on 5 April 1949, emphasized that Japan would be treated as an ally rather than an occupied power. This approach would undermine Soviet propaganda, which claimed that the United States was a colonial power, and stimulate economic growth, thereby negating the possibility of an internal Communist takeover of power. U.S. support 
would also ensure the revitalization of Japan's industrial base, allowing Japan itself to play an important role in containing Soviet expansion. ${ }^{29}$

Whilst the likes of General Douglas MacArthur, Supreme Commander for the Allied Powers in Japan, argued that the re-industrialization of Japan was unnecessary for containing Communist influence in the region, Mao's victory swept away his objections. Thereafter, MacArthur, like most senior U.S. officials, believed that Japan would have to act as a central hub for resisting Communist influence in the Pacific. ${ }^{30}$ The Truman administration subsequently decided that such a security role required a Japanese peace treaty, thereby ending U.S. occupation and facilitating economic recovery. Creating a Japanese peace treaty on a lenient basis thus assumed top priority in Washington's strategy towards the Pacific. ${ }^{31}$

\section{Australia and New Zealand}

The relationship between America, Australia, and New Zealand complicated progress towards a Japanese peace treaty. Although it is important to recognize differences between the two antipodean states, their positions often aligned neatly. Indeed, antipodean anxieties about a rearmed Japan manifested themselves into an uncooperative attitude towards the idea of a lenient Japanese peace treaty. ${ }^{32}$ From Canberra and Wellington's perspective, it was essential to avoid a repeat of the disaster of 1942 when the British Army had collapsed in Singapore and America had retreated from the Philippines, leaving Australia and New Zealand exposed to an expansionist rival with greater military strength. While Australian and New Zealand forces were engaged in fighting German and Italian forces in Northern Africa, Japan had struck the Australian mainland in 1941 and 1942, bombing Darwin and sinking naval vessels in Sydney harbor with midget submarines. ${ }^{33}$ Within Australian policy-making circles, there was a sense that the United Kingdom had betrayed its obligations in the region. The decision of the United Kingdom and United States to pursue a "Germany first" strategy was hardly designed to convince policy makers in Australia and New Zealand that antipodean security was afforded top priority in London or Washington. The clear preference to the defense of the European and Middle Eastern theatres at the onset of the Cold War only soured opinion further in both Canberra and Wellington. ${ }^{34}$ 
Given the lack of direct security commitments to Australasia, it is little wonder that both Australian and New Zealand policy-makers believed that the continued occupation of Japan ensured regional security and prevented a repetition of the military disasters of $1941-2 .{ }^{35}$ The brutality with which the Japanese military conducted itself towards allied troops operating in the Pacific theatre, especially towards prisoners of war, only magnified these concerns. Successive Australian and New Zealand governments therefore placed the future of Japan at the forefront of their thinking. ${ }^{36}$ For the antipodean powers, throughout 1945-49, regional security concerns were therefore far more pressing than the broader Cold War. ${ }^{37}$ In sum, Australia did not wish to see a resurgent Japan that could once again strike southwards. Likewise, New Zealand regarded the possibility of Japanese resurgence with considerable apprehension. ${ }^{38}$ The New Zealand Department of External Affairs summarized its position clearly:

New Zealand's primary interest in the Japanese settlement is security...the lesson that we must draw from our experience is that no action we might take is in itself likely to make the Japanese feel goodwill for us, and any trust we put in Japanese promises or good faith or peaceful intentions is likely to prove misplaced. The history of Japanese preparations for aggression, the evidence that militarist projects won almost unanimous support of Japanese politicians, businessmen and workers, and the record of Japanese atrocities upon uniformed soldiers and defenseless civilians, makes it imperative that our primary aim should be to impose the most rigorous security control upon Japan. ${ }^{39}$

American talk of harnessing the economic and industrial potential of the region, even as a means of ensuring collective security in the Pacific against the growing influence of the Soviet Union, therefore raised alarm throughout antipodean policy-making circles.

Changing global circumstances, however, encouraged the Australian and New Zealand governments to re-align with their superpower ally. The collapsing influence of European colonial empires, coupled with rising nationalist movements in Southeast Asia, was of growing concern to security planners in Canberra and Wellington. As Japan returned to the Western orbit, Mao's China, 
which was funding insurgencies throughout Malaya and Indonesia, came to assume prominence. From the perspective of Australian and New Zealand strategic planners, the rise of Chinese power threatened a repeat of the Japanese threat of the Second World War. Given their own limited resources in relation to the possible external threats confronting them, securing some type of security alliance with an outside power was of paramount importance to both Australian and New Zealand policy-makers. $^{40}$

The antipodean governments also shared concerns about future defense provision in a rapidly transforming world. Although the Statute of Westminster (1931), which established legislative equality between self-governing Dominions and the United Kingdom, had given the Australian and New Zealand governments a greater say in the pursuit of their foreign policy, their failure to ratify the statute had meant that both had still largely followed the United Kingdom's lead on strategic policy. The Second World War, however, encouraged a change of approach in both Canberra and Wellington. ${ }^{41}$ The conflict had provided a practical demonstration that the United Kingdom was simply unable to provide adequate defense in the region. ${ }^{42}$ The agreement between the United States and United Kingdom in 1942 to make the defense of the Pacific region the primary responsibility of the American government ushered in a turning point in defense policy; Australia and New Zealand could no longer rely solely on its defensive alliance with the United Kingdom. ${ }^{43}$ As such, within the post-war defense planning between the antipodean powers and the United Kingdom, Australia would take the lead in formulating such plans. ${ }^{44}$ A U.S. State Department assessment of antipodean defense policy ably captures this shift. "The impact of the war," the document stressed, "has brought an awareness of the strategic dependence of New Zealand and Australia upon the U.S. for defense in the Pacific and of the importance of maintaining close and friendly relations with the U.S. and furthering cooperation between the two countries in matters connected with the Pacific area." ${ }^{45}$

Beyond the continuation of close relations with allied nations, Australia sought increased strategic cooperation with New Zealand - which came in the form of the ANZAC Pact in 1944—and the maintenance of security relationships with the United Kingdom. These relationships remained extremely close. Australia and New Zealand, for instance, were signatories to the SIGINT (signals intelligence, namely intelligence gathering) arrangement in the UKUSA agreement of March $1946 .{ }^{46}$ 
Such cooperation afforded antipodean policy-makers access to, and knowledge of, British and American strategic thinking. In exchange, however, the governments of Australia and New Zealand had to continue to commit military forces to the defense of the Middle East and Mediterranean. British policymakers saw the "front line" in any global war involving the Soviet Union in the Middle East and Europe and were keen to focus their resources accordingly. ${ }^{47}$

The difficulties surrounding negotiations during the Colombo Conference of January 1950 ably reflect these tensions as British and Australian representatives clashed over the strategic importance of British Commonwealth interests throughout the Pacific in relation to that of Western Europe, the Mediterranean, and the Middle East. ${ }^{48}$ The British government's refusal to accord the same priority to Pacific defense as it had to the Middle East and Europe did nothing to convince Australian policy-makers that their country would be defended in the event of a global war. As Percy Spender, the Australian minister for external affairs, outlined to his Cabinet colleagues, "It is above all becoming clear that the United Kingdom, with added commitments in the Middle East over and above its responsibilities to the North Atlantic Treaty Organization, will have few resources to spare for active participation in the defence of the Australasian region." ${ }^{49}$

Nevertheless, traditional security relationships endured, principally because few alternatives existed. The Australian and New Zealand security relationship with the United States was patchy in the absence of any formal mechanisms for the exchange of military information, joint planning, or staff talks. As Peter Fraser, the New Zealand prime minister between 1940-9 candidly admitted, his country could hardly be expected to compel the United States into entering a security alliance with New Zealand. Australian efforts to convince the Truman administration to do just that had proven unsuccessful. Washington was simply uninterested in entering a trilateral security pact. America's intensifying interest in Japan, however, would eventually present Australia and New Zealand with a diplomatic opportunity to achieve these goals. ${ }^{50}$

\section{The United Kingdom}

Successive post-war British governments found it increasingly difficult to uphold their global responsibilities. The Second World War had demonstrated the inability of the British Empire to 
maintain its territorial integrity in the face of aggression, inflamed nationalist passions, and heightened financial difficulties. Economic challenges proved ever more problematic. Under the Labour government of Clement Attlee, an ill-fated attempt at currency convertibility took place, which, when coupled to growing gold and dollar deficits, exposed the fragility of the British economy. Further cuts in military spending followed, contributing to the withdrawal of military forces from India, Greece, and Palestine. ${ }^{51}$

Whilst policy-makers in London accepted U.S. domination of strategic planning for Pacific defense as unavoidable, they nevertheless remained unwilling to abdicate all of their influence in the region. Indeed, the British government was anxious about the shifting balance of power. Reporting to the Cabinet in 1950, Secretary of State for Commonwealth Relations Patrick Gordon Walker provided a stern warning. "Our hold over Australia's loyalty and respect," he noted, "will depend upon our capacity to show vigour and leadership in the world's affairs. ${ }^{, 52}$ The 1945-6 ANZAM (Australia, New Zealand and Malaya) understanding serves as an important example of growing antipodean independence. Although never a formal defense treaty, there followed Staff Talks between Australia, New Zealand and the United Kingdom and informal interchanges of assessments, and defense preparations in the Pacific region were undertaken. ${ }^{53}$ Crucially, the ANZAM understanding accepted that Australia had a "special role" in the region: "In war, Australia would accept responsibility in conjunction with the United Kingdom and New Zealand for overall direction and control of operations (other than home defense) in ANZAM region." 54

The British government had therefore accepted that Australia would now lead British Commonwealth strategic planning in the Southwest Pacific. ${ }^{55}$ Nevertheless, British policy-makers still believed that they had legitimate interests in the region and such perceptions were at the heart of many of the difficulties within U.S.-UK and UK-Australian-New Zealand relations in the forthcoming years. ${ }^{56}$ Senior British ministers were especially concerned about expanding American influence in the region and the impact this would have on the antipodean powers. "We cannot ignore the danger that Australia," Gordon Walker warned, "will be drawn into the American orbit of civilisation."57

For British policy-makers, however, Pacific security remained a secondary concern, lagging behind the restoration of post-war Europe, defending the Middle East, and ensuring the continuation 
of Anglo-American cooperation..$^{58}$ During transatlantic discussions about the possibility of a Pacific security pact, the British made it clear that they attached primacy to the defense of Europe and the Middle East, and wanted to maintain the Australian and New Zealand commitment to the latter region. ${ }^{59}$ The Middle East was, in the minds of most British strategists, to be the first line of defense against the Soviet Union. This was due to its large oil reserves, its proximity to the Soviet Union, and its value as a buffer to Communist advances into both the Mediterranean and Africa ${ }^{60}$ A more hostile and global Cold War, however, would encourage both London and Washington to look more closely at the Pacific and consider closer cooperation with Australia and New Zealand.

\section{Explaining ANZUS}

Following the end of the Second World War, both the British and the American governments located their immediate interests in the European and Middle East theatres. ${ }^{61}$ Analysts in both countries, however, began to suspect that the Soviet Union was responsible for instigating a number of nationalist risings throughout the Pacific region. The U.S. Central Intelligence Agency noted that the USSR recognized the immediate advantages of denying the West access to Southeast Asia as it was currently the principal Western source for natural rubber and tin as well as a secondary source of petroleum. It was also a major source of food for India and Japan. The Western powers would therefore have serious problems adjusting to the loss of such supplies in the event of a Communist takeover in the region. ${ }^{6}$

The Malayan Emergency of 1948, which developed into a lengthy guerrilla war fought between British Commonwealth armed forces and the military arm of the Malayan Communist Party, stoked suspicions in London about Soviets intentions. Whilst of the opinion that the economic weakness of the Soviet Union would deter Soviet leaders from launching a war against the West until the mid-1950s, British security planners believed that Soviet interference globally would persist and thus continue to damage British national interests. ${ }^{63}$ Indeed, the potential loss of Malaya's dollar earnings would be a severe blow to the UK and thus indirectly to the U.S., while the consequent impact to strategic materials and balance of payment positions of the NATO countries would damage plans for NATO's armament. ${ }^{64}$ 
The possibility of victory for the Communists in China heightened such concerns. The British Joint Intelligence Committee concluded that without preventative action and substantial material support, the countries of Southeast Asia might fall under Communist control. ${ }^{65}$ Senior elements within the British government were evidently early advocates of the Domino Theory that would subsequently inform U.S. grand strategy in Indochina. Events in Southeast Asia subsequently took on much greater importance for British policy-makers. Continued UK military involvement in suppressing Communist insurgents during the Malayan Emergency testifies to this shift in thinking. ${ }^{66}$ Yet for American policymakers, there was still considerable reluctance about direct military engagement in the region. There was even less enthusiasm for the creation of some Pacific security pact. Political and economic concerns continued to inhibit involvement. As Acheson publically stated in May 1949, "As I have taken pains to make clear on several occasions, the United States is not currently considering participation in any further special collective defense arrangements other than the North Atlantic Treaty." ${ }^{\circ 7}$

Events in Korea, however, had a profound effect on U.S. thinking. The surprise of the North Korean invasion of the South in June 1950 caught the intelligence services of both the United States and United Kingdom unaware, invoking memories of Pearl Harbor for some American analysts. ${ }^{68}$ The response was a U.S. led United Nations "Police Action" under MacArthur. The situation confronting MacArthur was challenging. South Korean forces were retreating in disorder and the South's capital, Seoul, had fallen to the North. The remnants of the South Korean army, along with the reinforced UN contingent, soon became penned into the Pusan Perimeter, the southeastern corner of Korea, surrounded by their North Korean foes. At this stage of the war, defeat to Communist forces seemed likely. MacArthur's spectacular counterattack, via an amphibious landing at Inchon on September 15, 1950 , reversed the situation. By the end of the month, the northern forces had retreated across the $38^{\text {th }}$ parallel. ${ }^{69}$

MacArthur soon overplayed his hand as UN forces pursued the North Koreans across the $38^{\text {th }}$ parallel and moved towards the Yalu River. MacArthur misread the likely response of the PRC and, after an earlier attack by Chinese "volunteers" in October, there followed a full-scale assault against UN forces on November 25. Having downplayed the possibility of PRC intervention to his political 
masters in Washington, MacArthur now declared that the United States faced "an entirely new war." Indeed, significantly outnumbered by PRC forces in November and December, the UN swiftly retreated, allowing Seoul to fall once again. On December 16, President Truman declared a "national emergency" which "require[d] that the military, naval, air, and civilian defenses of this country be strengthened as speedily as possible to the end that we may be able to repel any and all threats against our national security." ${ }^{, 70}$ By the end of December, it appeared as if Communist forces would drive the UN from the Korean peninsula. As one military historian has noted, an "American Dunkirk loomed." ${ }^{, 71}$ By the end of February, under the direction of General Matthew Ridgeway, a semblance of stability had returned to the war. Nevertheless, given the turn of events, Acheson justifiably termed the unfolding drama as "December Despondency" in his memoirs. ${ }^{72}$

Such traumatic events catalyzed the Truman administration's efforts to construct an integrated national security apparatus. Only following the surprise of the Korean War, for instance, did the United States establish a centralized signals intelligence organization, namely the National Security Agency (NSA). America's European policy also evolved as the United States began to hasten its efforts to strengthen the NATO alliance, which would even see Secretary Acheson begin to push for the rearmament of West Germany. Events in Korea further helped to convince American policymakers of the urgency of settling the Japanese peace treaty in order to buttress the containment of Communism. ${ }^{73}$

Although encouraging the United States to look for strong and reliable regional allies within the Pacific to oppose Communism, and convinced that the Communist victory in China could precipitate a domino-like effect throughout the region, there remained strict limits to American commitments in the region. ${ }^{74}$ For example, Washington repeatedly rebuffed lobbying from Australian and New Zealand officials to establish a formal Pacific security pact. ${ }^{75}$ There were nevertheless subtle shifts in American thinking towards the idea of entering into limited agreements with regional powers for upholding U.S. security interests. ${ }^{76}$

Japan was at the heart of U.S. strategic planning in Asia as it was the only state in the region to possess the industrial means, labor resources, and strategic location with which to act as the primary defensive hub in the Pacific. ${ }^{77}$ Events in Korea had provided a timely reminder of Japanese 
utility as it served as a base for supplying UN forces. ${ }^{78}$ U.S. intelligence assessments argued that for all of these reasons, "Japan's ultimate political alignment will be a decisive factor in the balance of power in the Far East." ${ }^{, 79}$ Consequently, Japan would "unquestionably be one of the primary targets of the Soviets" in any future war. ${ }^{80}$ Washington's top priority thus became the creation of a Japanese peace treaty, which would end the occupation of Japan and begin to harness its economic and industrial potential in the containment of Communism. ${ }^{81}$

Central to achieving this outcome was a peace treaty that stipulated lenient terms. Dulles, the principal American negotiator, looked to draft a "treaty which invoked the spirit of forgiveness to overcome the spirit of vengefulness. ${ }^{" 82}$ Indicative of this leniency was Acheson's suggestion that Japan should pay no reparations to the victims of its wartime actions. ${ }^{83}$ Finalizing the terms of a Japanese peace treaty nevertheless remained a complex task. The Japanese instruments of surrender contained the signatures of 11 other powers, including both the United Kingdom and Australia as well the Soviet Union. A preliminary peace conference established in 1947 further complicated matters by mandating that any final peace treaty would require the approval of a two-thirds majority. Given the Cold War context, the United States was prepared to press ahead with a peace treaty that excluded the Soviet Union. ${ }^{84}$

As the State Department began to gauge the likely reaction of its allies to a non-punitive treaty, opposition quickly became apparent. Whilst the British government had previously pressed the Truman administration to create a Japanese peace treaty, it was unhappy with the current American proposals for a mixture of strategic and economic reasons. ${ }^{85}$ American plans seemed to suggest that Japan would enjoy unsupervised economic redevelopment, which risked aggression in the future in the absence of any safeguards. In addition, the American proposals suggested that Japan should pay no reparations to the victims of its actions. Retaining close links with numerous British Commonwealth states that had been the direct victims of Japanese behavior encouraged London to demand that some reparations had to be paid. ${ }^{86}$ Furthermore, Japan had been a major pre-war competitor for British commerce and enterprise throughout Asia. The United Kingdom had benefited from the void left by the collapse of the Japanese Empire throughout Southeast Asia after 1945. American insistence that Japan could not trade with the PRC, however, would force Tokyo to look 
towards Southeast Asia for commercial opportunities and markets presently dominated by the United Kingdom. ${ }^{87}$

London now sought to create its own Japanese peace treaty, which deeply concerned Washington. Dulles, special consul to the president and, in large measure, the man negotiating the terms of the proposed treaty, was skeptical. He believed that a British draft would "not adequately take account of what the United States believes to be its vital interests in this area." ${ }^{98}$ Although united by a desire for security in the region, the major powers evidently parted company over how best to achieve this objective. International wrangling proved corrosive. Dulles believed that the British government was encouraging the Australians to take an antagonistic line towards the Japanese peace treaty. ${ }^{89}$ Such suspicions were accurate as the British were working closely with their Commonwealth partners in opposing American influence over the Japanese peace treaty. ${ }^{90}$ American interests nevertheless largely won through as British policy-makers constantly saw their advice rebuffed during the negotiations over the Japanese Peace Treaty. ${ }^{91}$ The U.S. attached great importance to creating a peace treaty on its own terms. Indeed, Dulles had gone as far as to gauge whether or not the Japanese would agree to a peace treaty that did not include the British if they continued to oppose the U.S. draft. $^{92}$

Australia and New Zealand's position concerning Japan requires clarification. The Australian government stubbornly argued that any peace treaty had to prevent a resurgence of Japanese militarism. In the judgment of Australian officials, U.S. proposals would allow Japan complete freedom over its economic and industrial development without providing adequate safeguards against this economic power being utilized again for military purposes. New Zealand officials were equally aghast at U.S. proposals. ${ }^{93}$ Security concerns, however, were not the only drivers of antipodean diplomacy. Following America and Britain's sustained defense of Korea, Canberra had newfound confidence in existing security commitments. ${ }^{94}$ Indeed, after successive meetings with Australian officials, Acheson noted that Australian demands for a security pact did not reflect "security reasons," rather they served as a vehicle with which to achieve closer participation in all stages of Washington's high-level strategic planning. ${ }^{95}$ Thus, and contrary to American expectations, when Australian Prime Minister Sir Robert Menzies visited Washington in late July and early August 1950, he made no 
mention of a security pact to the president or his advisors. The prime minister instead focused his attention on securing financial support to implement a five-year Australian immigration and development program. ${ }^{96}$

The Australian government was also reluctant to pursue a security pact at this juncture simply because Australian policy-makers had concluded that the Truman administration would reject the idea out of hand. New Zealand officials agreed that the subject of a formal security pact was unlikely to receive U.S. support and was thus not worth pursuing. ${ }^{97}$ Such pessimism was well founded. By the winter of 1950, an opportunity to discuss a Pacific security pact emerged when Dulles met with New Zealand representatives. Dulles' opposition to establishing a Pacific Security Pact was evident. As noted by those in attendance, Dulles reasoned that there were compelling reasons why such an alliance was unwise: "first of all, that it gave rise to great embarrassment as to those who wish to be included. [Dulles] felt, moreover, that, as compared with Europe, there was lack of common civilization of real community of interest and trust among the diverse countries of the Pacific area." ${ }^{98}$ The likelihood of a full-scale Pacific security pact at this point therefore seemed remote. Yet, within Washington, opinion was shifting in favor of a limited security agreement between the United States and the antipodean powers. As Acheson noted, it was "politically necessary" to accommodate Australian demands concerning security cooperation, in part because the large-scale development program in Australia served U.S. interests and in part to garner a more cooperative position concerning the drafting of the Japanese peace treaty. ${ }^{99}$ Without Australian support for a peace treaty, the U.S. believed Menzies would pursue economic policies that could inhibit Japan's economic revival. Where Australia led, America believed New Zealand would follow. If both antipodean powers acted in such a fashion, it was feared that the United Kingdom would also follow suit. ${ }^{100}$ Such policies would undermine any Japanese economic revival and risked the internal stability of Japan. Replicating arguments about European economic recovery from the likes of Dean Acheson and George Marshall, Dulles argued that if Japan failed to improve its economy then it would be "futile to expect the Japanese to keep away from communism." ${ }^{101}$ Security cooperation could help to overcome these problems. In the minds of American policy-makers, then, economic and security concerns were 
interwoven. Indeed, the historical record offers many examples of the United States using its overseas security commitments to influence allies' economic policies to its benefit during the Cold War. ${ }^{102}$

Such concerns, which stretched across Southeast Asia, would become a recurring theme in future ANZUS meetings. ${ }^{103}$ It is difficult to exaggerate America's concern over foreign economic policy. The European Recovery Program, or Marshall Plan as it came to be known, was largely motivated by the belief that European living standards would not improve without economic recovery. Without such improvement, the promises of the Communist model would become difficult to resist, thereby improving the chances of a Soviet victory. In spite of the enormous resources pumped into Europe, however, the economic situation remained precarious. During a meeting between Truman and president-elect Eisenhower in 1952, for instance, both men agreed the economic underpinning of the Western alliance was "too flimsy for safety. The slightest diminution of American aid or American defense spending might produce economic consequences which might seriously weaken the countries most closely associated with [the] U.S." ${ }^{104}$ Eisenhower would echo such thinking once in office. ${ }^{105}$ Japan, and increasingly Australia, were simply too important from an economic standpoint to ignore. $^{106}$

In early 1951, Australia and New Zealand continued to make their opposition towards a nonpunitive settlement known. ${ }^{107}$ For the U.S. government, the diplomatic impasse was clear. In order to gain antipodean approval for a lenient Japanese peace treaty and thus ensure the necessary two-thirds support from the allied occupying powers, the United States would have to guarantee that the revitalization of Japan's economy would not lead to future military aggression. Progress therefore rested on America's ability to provide the Australian and New Zealand governments with a suitable security guarantee. After considerable deliberation, the ANZUS Treaty emerged as the best solution to this problem. The United States government would enter into a security pact if the antipodean powers agreed to the Japanese peace treaty. As Acheson wrote to Dulles,

the United States Government is willing to make a mutual assistance arrangement among the Pacific nations (Australia, New Zealand, the Philippines, Japan, the United States, and perhaps Indonesia) ... [but] the United States Government should agree to this 
course of action only as the other nations accept the general basis on which the United States is prepared to conclude a peace settlement with Japan ${ }^{108}$

Washington, both in public and private, made the link between the security pact and the successful conclusion of the Japanese peace treaty explicit. ${ }^{109}$ An interdepartmentally agreed National Intelligence Estimate makes this point clear: "A U.S. decision to assist Japanese rearmament would not cause seriously adverse reactions in any non-Communist country with major interest in the Far East. Australia and New Zealand, however, will require U.S. guarantees against future Japanese military aggression."

In discussion with Carl Berendsen, the New Zealand Ambassador to Washington, Dulles hinted that he would discuss the terms of some type of security guarantee to both Australia and New Zealand during his forthcoming tour of Asia. ${ }^{111}$ The possibility of some type of defense pact improved when Dean Rusk, the assistant secretary of state for far Eastern affairs, mentioned the possibility of a tripartite security agreement in conversation with New Zealand Prime Minister Sidney Holland in early February $1951 .{ }^{112}$ During subsequent meetings, Truman and Acheson hinted that the United States would countenance an American commitment to defend New Zealand if this would guarantee continued commitments to the Middle East and Mediterranean. ${ }^{113}$ Holland had also suggested a similar arrangement. The New Zealand prime minister accepted that the likelihood of a direct attack on his country "was remote," and thus military forces "could best be utilized in some other theater," but "New Zealand would have to know, in the event the unlikely occurred and they were attacked, that someone, preferably the United States, would 'give them a hand." "114 These events, then, form the background for Dulles' visit to Canberra in February 1951 where the crucial discussions took place concerning the creation of the ANZUS Treaty.

\section{The Canberra Talks}

Once the respective delegations convened in Canberra in February, negotiations about the nature of a Japanese peace settlement and a security pact began in earnest. Spender stressed that a lenient Japanese peace settlement, which did not in turn provide some type of security guarantee, would 
ultimately lead Australia to reassess its Cold War commitments. In such a situation, "Australia’s capacity to discharge her obligations in the event of war in Malaya as well as outside the Pacific area would be gravely impaired." ${ }^{115}$ Both Spender and his New Zealand counterpart Frederick Doidge made good use of their respective countries' commitments to the Middle East in persuading Dulles of the merits of a tripartite security guarantee. ${ }^{116}$ Spender went on to suggest that a tripartite security organization between the United States, Australia and New Zealand would provide the necessary security guarantees for both antipodean powers to support a lenient Japanese peace treaty. ${ }^{117}$ Over the next two days, Doidge supported Spender's fundamental points. Antipodean endorsement for a lenient Japanese peace settlement would require a security guarantee from the United States. ${ }^{118}$

Dulles questioned the necessity of such an arrangement given the negligible threat of a direct Communist attack on either Australia or New Zealand. Spender responded skillfully, arguing that because the risk of a Communist attack was negligible, the U.S. could provide a security guarantee without fear of its use. ${ }^{119}$ In response, Dulles stressed that if the United States agreed to the tripartite security arrangement, any security pact would contain no formal pledge in the fashion of the NATO alliance. Moreover, the United States would not station its troops in Australia or New Zealand in advance of an attack upon them, as it did with NATO. ${ }^{120}$ Following further discussions about the nature of the alliance, and possible expansion of the security pact to include the Philippines, the representatives reached agreement concerning the general contours of the ANZUS Treaty on February 17. There emerged a tripartite agreement without binding security terms. ${ }^{121}$ In assessing the terms of the Treaty, no single power achieved all of its objectives. Nevertheless, the resultant agreement benefited all of the participants.

From an Australian and New Zealand perspective, the agreement provided a security guarantee that offered assurances against resurgent Japanese militarism and against any attack from an outside power. Given that the New Zealand government believed that the best that they could hope for from the Canberra talks was some type of informal American defence commitment, the final agreement was therefore somewhat of a coup. ${ }^{122}$ Furthermore, as Canberra and Wellington well understood, if the United States was determined to push for Japanese reindustrialization and rearmament there was little that either antipodean power could do to stop it. The best way to prepare 
for the risk that Japan would again utilize its economic power in the pursuit of military aggrandisement was to obtain a direct security guarantee from the United States. At the end of the Canberra talks, the antipodean powers have achieved this objective. ${ }^{123}$

Furthermore, Australian and New Zealand policy-makers never seriously countenanced neutrality in the Cold War. The Soviet Union was a clear and present security threat that both states wished to contain. ${ }^{124}$ A security pact with the United States, which Doidge referred to as "the richest prize in New Zealand diplomacy," would allow both antipodean powers to maintain their Cold War commitments. ${ }^{125}$ It is no surprise, then, that Berendsen concluded that the United States had "offered on a platter the greatest gift that the most powerful country in the world can offer to a small comparatively helpless group of people." ${ }^{, 26}$ A security guarantee from the United States would therefore defend against the Soviet Union and its Communist satellites in the short-term and defend against potential Asian expansionism in the long-term. ${ }^{127}$

Nevertheless, the agreement was limited in several regards. No mechanism emerged with which to secure access to other areas of U.S. strategic thinking. Specifically, the Australian government had sought to link the ANZUS agreement with the regular exchanges of information and staff officers with the U.S. defense establishment. ${ }^{128}$ The New Zealand government had also desired a greater voice in international security arrangements. ${ }^{129}$ The U.S. Joint Chiefs of Staff (JCS), however, were unwilling to allow more service chiefs in Washington than necessary. As a general point, the JCS were "lukewarm" about ANZUS and they reportedly viewed it as "of no great importance."130 Communist agents' successful infiltration of the Australian government did little to encourage cooperation. Indeed, on learning of this security breach, Washington had consequently refused to exchange further intelligence information with Canberra. In order to restore the intelligence relationship, the United Kingdom had to send a delegation from MI5, its own internal security organisation, to help their Australian counterparts improve internal security practices. The JCS were thus unlikely to welcome the possibility of exchanging further information with an outside power that exhibited such security lapses, especially given the persistent criticisms of the Truman administration and its supposed weakness against internal Communist threats. ${ }^{131}$ Thus the United States swiftly rejected Spender's attempts in the Canberra talks to "establish a framework of formal consultation 
and...provide a link with the North Atlantic Treaty Organization."132 Efforts by antipodean policymakers to utilize their newfound security relationship evidently failed at this point to lead to broader strategic cooperation between America, Australia, and New Zealand.

The United States certainly benefited from the agreement. It achieved the ambition of securing antipodean cooperation towards the American inspired peace settlement with Japan, which policy-makers believed to be of even greater importance throughout $1951 .{ }^{133}$ Dulles had also ensured that that the Treaty was limited in nature and scope, disappointing Australian and New Zealand efforts to establish integrated military planning. ${ }^{134}$ At no point did the Treaty guarantee joint staff talks or strategic planning, concessions that would turn the idea of a pact into a functioning security alliance. In addition, by agreeing to the ANZUS Treaty, the United States received a guarantee from both Australia and New Zealand to maintain their commitment to the defense of the Middle East and Mediterranean, areas that had come to assume great importance within U.S. strategic thinking, and to remain active the Cold War more broadly. ${ }^{135}$

This outcome is not to suggest that Australian or New Zealand diplomats had been blindsided. Since coming to office, Menzies had made it known that he wanted Australia to take a more active role in the Cold War, and refrain from the "busy-body" approach adopted by the preceding Chifley government. He wanted Australian forces to be committed to a region where they would actually have an impact on the outcome of any future global war. For Menzies, committing Australian forces to the defense of the Middle East and Mediterranean made strategic sense. ${ }^{136}$ Likewise, by the beginning of 1950, New Zealand officials had concluded that a third world war instigated by the Soviet Union was increasingly likely. One appraisal of the world situation composed by Berendsen mirrors the more damning indictments of Soviet intentions that are traditionally associated with the likes of John Foster Dulles and Paul Nitze. Berendsen believed that the Soviet Union sought "domination of the world" and was led by "international gangsters." The world situation was, he concluded, "a struggle between two totally incompatible and irreconcilable theories of human relations and human government."137 The New Zealand Joint Planning Committee was equally clear when it claimed that the "only possible enemy in the foreseeable future is the Soviet Union acting with the assistance of her European and 
Asiatic satellites." ${ }^{138}$ Both antipodean states therefore were committed to fighting the Cold War and the ANZUS arrangement complemented this ambition.

Beyond ensuring broader security interests, the U.S. enjoyed several economic benefits from the successful conclusion of negotiations. ANZUS complemented a broader attempt by the Truman administration to strengthen its economic position throughout Southeast Asia. The U.S. State Department was already concerned about the exclusive nature of economic cooperation between the United Kingdom and the two antipodean powers. The former Dominions' temporary wartime bulk purchase agreements, aspects of which continued for several years after hostilities had ended, were especially troubling. Such agreements, by channelizing trade, threatened to undermine the structure of international trade and impede Japanese revival. While America would not break these historic trade connections, the Treaty helped to build confidence in Australia and New Zealand to improve trade relations with Japan. In so doing, it provided an opportunity to question the imperial preference of commercial policies in the region, which the United States had actively sought to end since the Second World War. ${ }^{139}$

Indeed, before the Treaty was agreed, the State Department had stressed the need to "continue to point out to Australian officials the economic objections to such [trade] arrangements." ${ }^{40}$ ANZUS provided a potentially useful platform to encourage the antipodeans to "gradually counteract the narrow trade concepts of the past," thereby strengthening international trade in general and Japanese recovery in particular. ${ }^{141}$ As Clifton Webb, the New Zealand minister of justice and close confident of the prime minister, noted in Cabinet discussion, the creation of ANZUS meant that New Zealand could no longer "pound the table on the matter of imperial preference." 142 In this way, ANZUS respected the Truman administration's belief that the United States could pursue economic and security objectives in tandem. ${ }^{143}$

Yet even the United States could not obtain all that it wanted. Prior to the Canberra talks, Acheson instructed Dulles to negotiate a wider security pact. Dulles followed his instructions, and called for ANZUS to include membership for at least the Philippines. Spender and Doidge successfully resisted Dulles' efforts, although both had in fact left the meeting believing that the Philippines was likely to be included as a founder member of ANZUS. ${ }^{144}$ Antipodean resistance to 
Philippine membership reflected a mix of geopolitical, security, and racial motivations. Australia and New Zealand were determined to be treated as "Western" powers and were committed to play an important role in the Cold War. A security pact that included the Philippines would signal that both were in fact Southeast Asian powers and could limit antipodean ambitions of influencing U.S. strategy beyond the Southwest Pacific region. ${ }^{145}$ A pact involving Asian powers could also potentially drag both states into the defense of areas that had no direct bearing on their own interests. ${ }^{146}$ Racial and cultural assumptions also informed antipodean thinking. As Alan Watt, the secretary to the Department of External Affairs in Australia, candidly admitted in private discussions with his New Zealand colleagues, there were three overarching reasons why Australia desired a security guarantee from the United States. These were to counter against a rearmed Japan, against Communist imperialism in Asia, and "against Asian expansionism generally." As the record of this conversation noted, "The third reason, which [Watt] agreed was the strongest, could not, however, be made public." ${ }^{" 147}$ Race and culture, therefore, provide additional explanatory tools for understanding the nature of the ANZUS Treaty.

Antipodean resistance, supported by the United Kingdom, encouraged the United States to forego Philippine membership and instead conclude a bilateral agreement, entitled the U.S.-Philippine Mutual Assistance Treaty, in August 1951. The British government certainly exerted influence over the final membership of ANZUS. Indeed, British opposition to a broader and more inclusive Pacific security pact helps to explain the exclusion of other regional powers from ANZUS. The British could tolerate their own omission from a strictly tripartite alliance, albeit only for the time being, but if a broader Asian security alliance emerged, then British policy-makers would demand membership of such a pact. ${ }^{148}$ The limited tripartite nature of the agreement therefore reflects the influence of four, rather than three, states. The ANZUS agreement was also of indirect benefit for British interests because it provided the regional security guarantees that in turn allowed both Canberra and Wellington to commit their forces to the Middle East and Mediterranean in the event of a war with the Soviet Union. ${ }^{149}$

Nevertheless, the United Kingdom remained uneasy about the Treaty. Throughout the creation of ANZUS, the British government was excluded from the process and largely ignorant of 
the details. British officials had made it known to their Australian and New Zealand counterparts that they would not "favour the idea of a Pacific defence organisation which excluded the United Kingdom," but this proved to be the very result of the Canberra talks. ${ }^{150}$ As one historian has noted, British policy-makers did not deem Australia or New Zealand to be a "foreign country," yet during the creation of ANZUS both had acted as such. The affinity of Empire and common kinship was limited in the face of geopolitical realities. As Doidge remarked in one cabinet session, the fact was "Britannia no longer ruled the waves" and New Zealand would thus have to guarantee its security through a pact with the United States. ${ }^{151}$ Spender's assessment during the talks was also clear: "Australia was a principal in the area but the United Kingdom was not." ${ }^{, 152}$ British objections, as Menzies noted to Holland, would not prevent the creation of a tripartite security pact with the United States. $^{153}$

America had never seriously considered the United Kingdom as a key member of any future security pact in Asia. In contrast, the Philippines, Japan, Australia and New Zealand repeatedly appeared as the key states in American policy-making conversations. ${ }^{154}$ When Britain did feature, it was often regarding trading and economic practices that undermined broader U.S. geopolitical objectives. ${ }^{155}$ America largely considered the British to be of marginal importance as an ally in resisting Communism throughout the Pacific. As Dulles noted to MacArthur, "The United States and Japan are the only significant sources of power in the Pacific, we actual, they potential." ${ }^{, 156}$ Such was the honesty, or perhaps insensitivity to British sensibilities, that both Dulles and Acheson would repeat this point in discussion with British officials. ${ }^{157}$

Suggestions that Anglo-American differences over the creation of ANZUS were limited, or reflected "clumsy diplomacy and personal obstinacies," downplay British interests in the region. ${ }^{158}$ The British government saw its omission as detrimental to its national interests, reflecting concerns beyond mere self-esteem. As British policy-makers feared, exclusion meant that if ANZUS either materialized into a broader alliance or began to involve strategic planning, the United Kingdom would find itself on the outside unable to influence the course of events. ${ }^{159}$ British policy-makers were right to be concerned about their exclusion from ANZUS. By the end of 1953, encouraged by U.S. policymakers in forums created by ANZUS, both Australia and New Zealand re-positioned their strategic 
planning to defend Malaya instead of the Middle East in line with growing American concerns about the growing threat posed by Communist forces in Southeast Asia. ${ }^{160}$

During cabinet discussions, Prime Minister Clement Attlee had suggested in the face of opposition that ANZUS aligned with the overarching British policy to encourage allies to provide for their own national defense. ${ }^{161}$ Competing accounts and the actions of British diplomats contradict Attlee's position. Lobbying of U.S., Australian and New Zealand officials in the lead-up to the Canberra talks to prevent their exclusion from any security pact had proven unsuccessful. ${ }^{162}$ Foreign Secretary Herbert Morrison also complained to Dulles that American public announcements about the negotiating of the ANZUS Treaty undermined the illusion that the British government was involved in the negotiations, removing even the veneer of influence. Moreover, the United Kingdom's exclusion from a defense treaty with two of its Dominion powers hardly supported British ambitions of retaining world power status. ${ }^{163}$ Although on balance the antipodean powers would have preferred British inclusion at that time, American support was essential. Spender was therefore unwilling to see his designs for a security treaty scuppered by British complaints. He remained insistent throughout his negotiations with Dulles that British grievances concerning exclusion were groundless and should be disregarded. ${ }^{164}$

The timing of the ANZUS Treaty also complemented important economic shifts away from British interests. As Australia's goals for diversifying its industrial structure developed, the United Kingdom had struggled to provide the necessary capital. Australia subsequently renegotiated its trade relations in the 1950s and placed more emphasis on relations with the United States. ${ }^{165}$ Economic recovery throughout Asia, along with the liberalization of trading practices, weakened Britain's privilege within the imperial trading system and encouraged rival markets for potential Australian goods and services. By the late 1960s, Japan had become a more important market for Australian products than the United Kingdom. ${ }^{166}$ In facilitating a non-punitive Japanese peace treaty, and providing the U.S. with a stronger political position from which to discuss discriminatory trading policies with the antipodean powers, exclusion from the ANZUS agreement ultimately proved to be a costly failure for the British government. 


\section{Maintaining British exclusion}

All three signatories of ANZUS had agreed to exclude the United Kingdom from membership. Of the three, London rightly perceived the United States to be the driving force behind this decision. ${ }^{167}$ Explanations for exclusion, however, differed on either side of the Atlantic. Senior elements within the Labour government and the Conservative opposition believed exclusion reflected Attlee's earlier decision to recognize the PRC despite American protests. Such arguments are unconvincing. London's recognition of the PRC was certainly distasteful to Washington but had not undermined cooperation in many other areas of alliance security policy. ${ }^{168}$ Limited mention of the United Kingdom's China policy in U.S. documentation concerning membership of ANZUS also makes such explanations difficult to substantiate.

American explanations publically centered on the idea of race. U.S. officials suggested that British exclusion from ANZUS reflected anxieties about an "Anglo-Saxon or White Man's Club" in Asia. ${ }^{169}$ British membership would create such a club, whereas a limited tripartite agreement would help to win the propaganda battle against the Soviet Union, pacify continued international complaints about U.S. domestic racism, and placate potential criticism from allies such as the Philippines that were themselves seeking a security alliance with the United States. ${ }^{170}$ Historians have paid a great deal of attention to the categorization of groups for many decades, producing a rich and diverse historiography concerning domestic politics. ${ }^{171}$ Diplomatic historians have also found race to be especially relevant to U.S. foreign policy in Asia during the Second World War and in the post-war period. ${ }^{172}$ In relation to ANZUS, however, historians have largely overlooked the issue.

Concerns about race were certainly important to key U.S. policy-makers. During the negotiations of the Japanese Peace Treaty, for instance, Dulles was anxious that Asian countries might perceive U.S. policy as racist because of their exclusion from the negotiations. Such tensions could undermine his chances of successfully concluding a treaty. ${ }^{173}$ Regarding ANZUS, Dulles was concerned about an exclusively "white" security pact. As one memorandum makes clear, "There was a danger that a security pact limited to the three white Pacific nations would raise serious political problem for the United States in the Philippines, and [Dulles] felt that, for that reason, his Government might wish to ask that the Philippines be admitted as an original party." ${ }^{174}$ This was the 
very objective that Dulles had pursued during the Canberra Talks, albeit unsuccessfully. In addition, he was concerned with American race relations, both domestically and internationally, and how such a treaty could undermine the U.S. in its struggle against Communism. ${ }^{175}$

Nevertheless, explanations for British exclusion based on race are only partially convincing. Onlookers would surely struggle to see the addition of Britain to ANZUS, given existing alliances with its three members, as "unnatural." Moreover, the creation of ANZUS with Australia and New Zealand was, for all intents and purposes, a "White Man's Club" given the "White Australia" and "White New Zealand" immigration policies maintained at this time. ${ }^{176}$ Furthermore, when surveying the documentary evidence, it is apparent that ethnic or ideological concerns were not the determining factors guiding American foreign policy in the region. "Race," specifically repeated references to a "White Man's Club," was instead often utilized by American policy-makers as a diplomatic tool. Such terminology obscured the pursuit of American geopolitical and economic interests in the region. Scholars should therefore look to ideas about race to complement, rather than replace, existing accounts of U.S. foreign policy vis-à-vis the ANZUS Treaty and broader security strategies throughout the Pacific. ${ }^{177}$

America's decision to exclude Britain from ANZUS largely reflected two material concerns. The first revolved around a continued fear within the U.S. policy-making establishment that America could simply not afford to create a NATO style pact in Asia, which would inevitably involve a major contribution from the American Treasury. The election of the Eisenhower administration, which was determined to control rising American public expenditure, meant that without some significant external developments, increased spending was unlikely. ${ }^{178}$ The second problem was that broadening the defense pact could invite other European powers to manipulate the United States into defending their colonial possessions under the guise of fighting against Communism. ${ }^{179}$ As the British were involved in a counterinsurgency war in Malaya, which involved a contribution from Australian and New Zealand forces, such fears appeared reasonable. Moreover, the Joint Chiefs only accepted ANZUS as it currently stood because it was an essential prerequisite for gaining Australian approval for the Japanese peace treaty. ${ }^{180}$ 
The Attlee government had sought to downplay British exclusion from ANZUS, but electoral defeat brought with it a reversal in policy. On October 26, 1951, Prime Minister Winston Churchill returned to office with a small parliamentary majority. Churchill had returned to Downing Street for his final premiership at the age of almost seventy-seven. ${ }^{181}$ It did not take long for the prime minister to demand membership of ANZUS. Churchill's belief in the connection between the "Mother Country" and the "Dominions" was strong. Nevertheless, his actions in the Second World War, which had effectively left Australia and New Zealand to fend for themselves against Japanese aggression, had demonstrated his pragmatism in foreign policy. ${ }^{182}$

As events in Asia became increasingly important to the course of the Cold War, inclusion in ANZUS could potentially allow the United Kingdom to exert more influence over American thinking in the region. In keeping with British grand strategy, close U.S.-UK relations were necessary in order to "guide" the United States in the struggle against Communism. ${ }^{183}$ Furthermore, Churchill had become increasingly worried about the likelihood of a global war, prompted by both Soviet and U.S. belligerency. Such concerns encouraged the prime minister's belief that the British should play a major role in a broader defense treaty in the Pacific, something he would term a "Pacific Defence Pact," that would include the ANZUS members, the United Kingdom, France, and several other Asian states. $^{184}$

Gaining entry into ANZUS became a priority for Churchill and consequently led to a twopronged diplomatic effort. The first involved directly lobbying Washington, which occurred on numerous occasions throughout 1951-3. The second utilized direct appeals to both the Australian and New Zealand governments for them to lobby the United States on Britain's behalf. ${ }^{185}$ Thus, throughout his efforts to achieve membership, and in an effort to gain political leverage over the United States, Churchill sought to establish stronger ties with the Australian and New Zealand governments. Such attempts came in the form of detailed staff talks about how to uphold security throughout the ANZAM region in the longer-term. ${ }^{186}$ As the British government took greater interest in the region, it also sought to establish a closer security partnership with Australia and New Zealand, which would come in the guise of a broader Pacific security framework. Churchill envisaged that this 
partnership would have a central machinery of control for the wider Pacific area, including Southeast Asia. ${ }^{187}$ The two-pronged approach, however, would ultimately fail.

Both Canberra and Wellington gave Churchill's ideas considerable thought. In April 1952, Holland confirmed that, "the United Kingdom must be brought in" to ANZUS. ${ }^{188}$ Menzies was also interested in British membership. He believed that Churchill's ideas provided the opportunity for turning ANZUS into a functioning security alliance that would include detailed strategic planning. As the Australian prime minister suggested to his closest security advisers, British membership increased the likelihood of strategic planning discussions between members and would increase the level of importance attached to the defense of the Pacific in both British and American grand strategy. ${ }^{189}$ There was considerable sympathy for Menzies' thinking, not least from the Australian Defence Department. As strategic planning between Australia, New Zealand, and the United Kingdom already existed within the context of ANZAM, it was illogical to replicate this within the framework of some future ANZUS planning that omitted the British entirely. In addition, in the event of a global war, Britain's military contribution would be imperative to ensuring that Australian sea-lanes remained open. Finding a solution to British omission from ANZUS was therefore important. ${ }^{190}$

Policy-makers in Washington, whilst less susceptible to British arguments, were thus forced to confront the issue of British exclusion from ANZUS early on. The first meeting of the ANZUS council, held in Honolulu, Hawaii from August 4-6, 1952, surrendered a considerable amount of time to the topic. ${ }^{191}$ In discussion, the Australian and New Zealand representatives raised the case for British membership. Such efforts perhaps revealed lingering imperial ties, but more likely reflected a belief that British membership would bolster chances of creating a NATO like security pact, introducing all of the strategic benefits this afforded. Nevertheless, the Australian and New Zealand delegations were more concerned with trying to convince the Americans to begin detailed military discussions within the framework of ANZUS. Indeed, the difficulty of securing military collaboration eventually sidelined discussions concerning British membership of ANZUS.

During the talks, the U.S. rebuffed all advances for joint military planning. Efforts to enlarge ANZUS, and thus accrue the strategic and military planning benefits via the "backdoor," proved equally futile. At the conclusion of the conference, the participants issued a joint communiqué. While 
not strictly forbidding British membership of ANZUS, it was clear that none of the member states were now looking to expand membership in the immediate future. Australia and New Zealand might have preferred British membership, but they were unwilling to endanger the nascent Treaty to achieve this outcome. ${ }^{192}$ Policy-makers in Canberra and Wellington feared that Washington would misconstrue efforts to expand membership as an effort by former colonial powers to uphold their interests in the Pacific and Southeast Asia more generally. The United States, Australian officials noted, may then decide to retract their commitment to Australian defense. ${ }^{193}$ American objections towards British membership thus prevailed.

The public communique issued at the end of the conference suggested that the United Kingdom would be permanently excluded from ANZUS. London nevertheless sought confirmation via sources within the New Zealand government. The response, which confirmed initial suspicions, left senior policy-makers seething. ${ }^{194}$ "What impudence to suggest that France and I suppose Portugal (who has interests in these waters)," Churchill wrote to British Foreign Secretary Anthony Eden, "are on the same terms with Australia and New Zealand as Britain. If this point became public in either of these countries, I am sure that there would be a violent re-action." ${ }^{195}$ Lord Salisbury, the minister of state for the Dominions, was equally disdainful, suggesting that the attitude of the Dominions was “deplorable" and "tiresome." ${ }^{196}$ Exclusion from ANZUS was evidently a serious affront and many senior political figures perceived it to have had damaging implications for legitimate British interests in the region. These responses indicate that British policy-makers never saw their exclusion as merely a case of hurting British prestige. ${ }^{197}$ Instead, British policy-makers feared their continued exclusion from ANZUS meant that that United Kingdom had lost the ability to "guide" Western strategy in the region.

The obstacle to British membership had been largely American in nature. Yet, when British officials pressed their American counterparts, they only received vague excuses. Acheson repeatedly explained that ANZUS could not expand to include other members because it would encounter enormous domestic-political opposition from the United Sates Congress. In addition, an expanded ANZUS would appear as a "White Man's Pact" that was "cloaking some new form of Imperialism." ${ }^{198}$ These utterances ably reflect America's use of race as a diplomatic tool in the post- 
war period. Such an explanation was a much more convenient excuse for America than justifying British exclusion because of lingering doubts about discriminatory trading practices between Australia and Britain, fears about new strategic commitments, or concerns about the costs of defending European colonial assets. ${ }^{199}$

As a tool for cloaking real American intentions, however, the race argument was deficient. The British Chiefs of Staff recognized that far less altruistic reasons governed American policy. Mirroring the types of complaints made during World War II, the Chiefs complained that, "The United States desire to keep control of Far East planning in their own hands, and their own attitude towards ANZUS is governed by that desire." ${ }^{200}$ Likewise, British officials in the foreign office complained that the American argument lacked substance. British exclusion, in their assessment, had little to do with the fear of creating a "White Man's Club" and much more to do with the American desire to exclude the United Kingdom from strategic planning and to weaken their preferential economic position throughout the region. ${ }^{201}$ Yet, in a perverse fashion, such excuses allowed the British government to save face. Fairness, not weakness, appeared to explain British exclusion to international onlookers, which perhaps explains the persistence of this particular diplomatic excuse.

While British ministers and officials believed they had little chance of joining ANZUS whilst Truman and Acheson occupied the White House, the election of Dwight D. Eisenhower in November 1952 raised hopes that a change in U.S. policy would be forthcoming. ${ }^{202}$ The president's decision to appoint John Foster Dulles as his secretary of state soon dashed such optimism. Dulles, disliked by both Churchill and Eden, had negotiated the Japanese Peace Treaty and the creation of the ANZUS Treaty. His conduct during both demonstrated his willingness to ignore British sensitivities. ${ }^{203}$ Eden and Churchill spoke privately with Eisenhower in January 1953, which only reinforced their concerns, as the president-elect appeared uninterested in the subject of expanding ANZUS membership. ${ }^{204}$ Despite a change of personnel, however, the excuses remained consistent. Dulles emphasized his concern that ANZUS should not appear to be a "White Man's Club" in Asia. ${ }^{205}$

Although Eisenhower appeared uninterested in British membership of ANZUS, Churchill was confident he would be able to influence the president owing to their close cooperation during the Second World War. Throughout 1953, he redoubled his efforts to gain entry. Churchill also planned 
to push his latest idea about the creation of a Five Power Pact-involving the U.S., Australia, New Zealand, Britain and France — or a broader NATO-like security arrangement for the region that would expand the membership of ANZUS. European powers, such as the United Kingdom and France, would join with Asian powers such as the Philippines, Singapore, Malaya, India and Pakistan, in a new security alliance. ${ }^{206}$ The inclusion of these "non-white" powers would help to undermine the U.S. racial argument, which opposed a broader security alliance that included the United Kingdom.

Churchill, however, had fundamentally misread the foreign policy intentions of the ANZUS powers. In Australian and New Zealand policy-making circles, the idea of a Five Power Pact was unappealing as it threatened to downgrade their status vis-à-vis the United States. More worrying yet was the continuing Australian suspicion that British proposals were a ploy designed to destroy ANZUS. As Percy Spender, now Australian ambassador to the United States warned from Washington:

I know the grand old man [Churchill], does not like ANZUS and will do his best to reduce it to bare bones- perhaps by putting forward the Five Power Staff Agency, and by seeking agreement to broad political directives- which can always be interpreted as one is disposed to interpret them- directed to the Staff agency. But we have achieved a special place in the Pacific through ANZUS and I know you will forgive me when I say, we must hang on to it. ${ }^{207}$

Regardless of London's efforts, the Eisenhower administration was also unlikely to welcome a broader security alliance in the Pacific. Such a commitment would require additional funding which ran contrary to the administration's serious efforts to reduce U.S. public expenditure on defense. ${ }^{208}$ Indeed, it was only following the collapse of the French in Indochina in 1954 that a real change in U.S. thinking concerning the region emerged. Only then would the U.S. government seriously consider a Pacific security pact. Although these events led to the creation of the South East Asia Treaty Organization (SEATO), even this international organization for collective defense remained heavily reliant on nuclear arms and many historians consider it to have been a "failed alliance."209 
As the United States continued to oppose British membership of ANZUS, Churchill looked for support elsewhere. Meeting with Menzies and Holland in June 1953, he took the opportunity to press his case. Churchill started the meeting with a plea that exclusion ran "contrary to United Kingdom interests, and was objectionable on both military and political grounds. ${ }^{, 210}$ Stressing that relations "might be impaired in [the] future if a solution were not found to the problem of planning Pacific strategy," he concluded that "in view of the difficulty of associating the United Kingdom with ANZUS, some wider form of Pacific pact should be considered." ${ }^{211}$ The response was lackluster. Both Menzies and Holland refused to confirm whether they would support the prime minister's proposals. Following further reflection in Canberra and Wellington, Churchill's proposals received a lukewarm response.

Any lingering Australian sympathies had now evaporated. Menzies made it clear that he would no longer allow ANZUS to be "disrupted" by the question of British admission. His foreign minister, Richard Casey, was also adamantly opposed to British membership. Casey resented the implication that the Australians required British "hand holding" in any alliance, and feared that pushing for a broader security pact could lead the United States to cut its existing security guarantees to Australia. Spender had also made a similar argument to Menzies in a lengthy note from Washington:

I specially want to stress, if we allow anything to interfere with ANZUS, whether on the political or military plane, we will lose the only means we have of any effective entry into USA political and military thinking at a high level and the intimacy which ANZUS unquestionably affords us. For the first time we have got a toe hold into the councils in the USA which affect the world and its destiny at a high and acknowledged level through ANZUS. I cannot tell you how glad I am that you are resolved that we shall not relinquish it. $^{212}$

Australian policy-makers had now concluded that the status quo was preferable. In New Zealand, there was considerably more sympathy for Churchill's plight, but progress also foundered on fears 
that pursuing such a path would jeopardize current U.S. commitments. In the final analysis, such a risk was not worth taking. ${ }^{213}$ Sentimentality and imperial bonds were evidently unable to overcome geopolitical realities.

Support for British membership within the antipodean countries continued to wane over the course of the year. "The ANZUS arrangement," Menzies explained to Churchill, "has political reality in New Zealand and the United States as well as in Australia. It is a political fact of the first magnitude. In any of these countries, moves which had the effect of destroying or even weakening this arrangement would be liable to serious misunderstanding." ${ }^{214}$ Familiar American excuses also now took root in the southern hemisphere as Australian policy-makers now began to suggest that British membership of ANZUS would create the impression that it was a "White Man's Club" and would therefore damage relations between its members and the other Asian powers. ${ }^{215}$ This racial explanation was largely disingenuous as the Australian decision to exclude the United Kingdom from ANZUS had little to do with racial equality. Such rhetoric, however, served as a useful excuse.

British representatives also encountered resistance from the New Zealand government. Holland, whilst more sympathetic to the British position, would not countenance alterations to the Treaty that could potentially undermine U.S. security commitments. Churchill's ambition of obtaining Australian and New Zealand support for a Pacific security pact therefore collapsed in the absence of any real enthusiasm. ${ }^{216}$ Evidence of such discussions also tempers claims of the "ANZAC dilemma." Australia and New Zealand may have felt "the pull between old habits of thought and emotion and the necessities imposed by geography and the present state of world affairs" but their preferences were sufficiently clear to lessen the difficulty of any such choice. ${ }^{217}$ Both the Australian and New Zealand governments were becoming increasingly skeptical about the benefits associated with British membership of ANZUS. ${ }^{218}$

Despite failing to convince their antipodean counterparts, Churchill and Eden persisted in bilateral diplomacy with the United States. Following his orders from London, the British ambassador to Washington, Oliver Franks, met with American representatives in September 1953. Membership, he learned, was no longer a possibility for the United Kingdom. The explanations offered in defense of this position included fears of a "White Man's Club," and the consequent possibility of French 
membership, which risked the costly expansion of ANZUS into Indochina. British hopes that Eisenhower's ascension to the presidency would help them to gain access to ANZUS had proved ill founded. ${ }^{219}$ Whilst Churchill and Eden accepted that the United Kingdom could no longer dominate Western strategy in the Pacific, now even a marginal role eluded them. Churchill had evidently overestimated his country's importance to the United States in relation to Pacific security. ${ }^{220}$

By late 1953, Dulles had made it abundantly clear that the United States would not countenance the possibility of British membership of ANZUS. In a thinly veiled threat to any potential supporters, he made it known that if the two antipodean states continued to pursue the matter then they would do so at the expense of the entire ANZUS relationship. As the Australians subsequently informed the British:

A decision was taken not to extend the membership of Anzus to include the United Kingdom. Mr Dulles at one stage professed readiness, if Australia and New Zealand, really wished it, to let the United Kingdom into Anzus. But he made it clear that if that happened, it would therefore be the end of Anzus as a treaty having any value to the three parties. ${ }^{221}$

It is possible that the Australians had exaggerated America's diplomatic approach in an effort to downplay their own interests, but such duplicity seems unlikely. The U.S. had been insistent on British exclusion from the very beginning and Dulles' diplomacy was certainly in character. Even if Dulles' behavior was merely an act of frustration or bravado, the fact remained that American strength allowed for the creation of an alliance predominantly on U.S. terms. Accordingly, a communiqué issued at the end of the 1953 ANZUS meeting explicitly ruled out extending membership. ${ }^{222}$

America's handling of its allies, and the issue of British membership more broadly, represents a subtle challenge to the existing Cold War historiography. Claims of "empire by invitation" tend to stress cooperation amongst alliance partners. Dulles' diplomacy with the antipodean powers complicates such assumptions. Nor were such negotiations an aberration for the period or the region. Marc Trachtenberg has similarly shown that the U.S. could treat its allies roughly if required to secure 
national interests. Such insights certainly challenge popular caricatures of America's handling of the Atlantic Alliance and there is good reason to believe similar methods extended to the Pacific. ${ }^{223}$ Reinforcing Dulles' rough diplomacy with Australia and New Zealand, America cemented its preference for a tripartite agreement without formal defense ties. Following the public announcement, Australian and New Zealand officials made it clear to their British counterparts that they would no longer push for expansion. ANZUS would remain as an exclusive tripartite pact.

\section{Conclusion}

The emergence of a formal security pact between America, Australia and New Zealand in the early 1950s reflected a compromise. The United States offered a limited security guarantee and in return obtained Australian and New Zealand support for a lenient Japanese Peace Treaty, which complemented broader American ambitions to contain Communism. The antipodean powers had also benefited as ANZUS addressed concerns about the threat of a resurgent Japan that had deeply troubled policy-makers in Australia and New Zealand. Though the security apparatus of the alliance was limited, it established an important precedent of strategic cooperation across the Pacific. The ANZUS Treaty therefore benefited all of its members.

The tripartite agreement could nevertheless discriminate in favor of Washington rather than those of Canberra or Wellington at times. Australian and New Zealand efforts to expand ANZUS' remit to include broader strategic cooperation and planning failed in the subsequent years. In addition, Australia and New Zealand grudgingly surrendered older traditions of cooperation with the United Kingdom under the pressure of American threats of withdrawal. The creation of ANZUS certainly came at the expense of the interests of the United Kingdom. Many senior British figures were determined to make the Treaty as irrelevant as possible if they could not achieve membership. ${ }^{224}$ The longevity of the ANZUS Treaty highlights both the futility of such ambitions and the enduring success of U.S. diplomacy in the Southwest Pacific. 


\section{Acknowledgments}

The authors are grateful to R. Gerald Hughes and Michael J. Gill for reading and reviewing earlier

versions of this article. We also wish to thank the two anonymous reviewers for their many insightful

suggestions. Any errors of fact or judgment are entirely our own.

${ }^{1}$ Officially known as The Pacific Security Treaty but referred to more commonly as ANZUS or the ANZUS
Treaty. New Zealand left ANZUS due to disagreements concerning Washington's nuclear policies in the 1980s:
Amy L. Catalinac, "Why New Zealand Took Itself out of ANZUS: Observing 'Opposition for Autonomy' in
Asymmetric Alliances," Foreign Policy Analysis, Vol. 6, No. 3 (2010), pp. 317-338.
${ }^{2}$ It stated, "The Parties will consult together whenever in the opinion of any of them the territorial integrity,
political independence or security of any of the Parties is threatened in the Pacific." For a full copy of the
ANZUS Treaty, see http://australianpolitics.com/topics/foreign-policy/anzus-treaty-text (Accessed 5 January
2014). The ANZUS Treaty was just one example within a broader framework of alliance building by the United
States during the early stages of the Cold War. The United States first built alliances within its own hemisphere
with the creation of the Rio Pact in 1947. In 1949, the North Atlantic Treaty Organization established its most far-reaching alliance with Europe and Canada.

${ }^{3}$ The Australian Foreign Minister Percy Spender provided a detailed account of the negotiations in his memoir published in 1969. Most historians initially took his account of events at face value. In the 1980s, a new wave of scholars began to challenge Spender's claims that ANZUS largely came into being because of his adroit diplomacy. See: Percy Spender, Exercises in Diplomacy: The ANZUS Treaty and the Colombo Plan (Sydney: Sydney University Press, 1969), pp. 13-190; Robert O'Neill, Australia in the Korean War 1950-53, Vol. 1: Strategy and Diplomacy (Canberra: Australia Government Printing Service, 1981), pp. 185-200; William David McIntyre, Background to the Anzus Pact: Policy-Making, Strategy and Diplomacy, 1945-55 (Basingstoke: Palgrave Macmillan, 1994); J.G. Starke, The ANZUS Treaty Alliance (Melbourne: PanBooks, 1965), pp. 1-75; Erik Olssen, "The Origins of ANZUS Reconsidered," Historical and Political Studies, Vol. 1, No. 2 (1970), pp. 102-10; David McLean, “Anzus Origins: A Reassessment,” Australian Historical Studies, Vol. 24, No. 94 (1990), pp. 64-82; Philip Dorling, The Origins of the Anzus Treaty: A Reconsideration (Adelaide: Flinders University Press, 1989); David Lowe, "Percy Spender's Quest," Australian Journal of International Affairs, Vol. 55, No. 2 (2001), pp. 187-198; Neville Meaney, "Look Back in Fear: Percy Spender, the Japanese Peace Treaty and the ANZUS Pact," in Roger Buckley et al. San Francisco: 50 Years On, Part 2 (London: The Suntory Centre, 2001), pp. 42-43. For a good overview of the debate, see Henry Albinski and William Tow, "ANZUS - Alive and Well after Fifty Years," Australian Journal of Politics and History, Vol. 48, No. 2 (2002), pp. 153-173.

${ }^{4}$ Dean Acheson, Present at the Creation: My Years in the State Department (New York: W.W. Norton, 1969), pp. pp. 586-8.

Robert Beisner, Dean Acheson: A Life (Oxford: Oxford University Press, 2006), p. 500.

${ }^{6}$ Glen St. J. Barclay, Friends in High Places: Australian-American Diplomatic Relations since 1945 (Oxford: Oxford University Press, 1985), p. 55; O’Neill, Australia in the Korean War, pp. 185-200.

${ }^{7}$ McLean, "Anzus Origins," pp. 64-82; Starke, The ANZUS Treaty Alliance, pp. 1-75; Olssen, "The Origins of ANZUS Reconsidered," pp. 102-10.

${ }^{8}$ Economic factors as a motivating factor in U.S. policy towards the creation of ANZUS receive limited attention in the following: David Lowe, Menzies and the "Great World Struggle": Australia's Cold War, 19481954 (Sydney: University of New South Wales Press, 1999); Beisner, Acheson; Ritchie Ovendale, The English Speaking Alliance: Britain, The United States, the Dominions and the Cold War, 1945-51 (London: Allen and Unwin, 1985); Peter Lowe, Containing the Cold War in East Asia: British policies towards Japan, China and Korean 1948-53 (Manchester: Manchester University Press, 1997); Lee, Outposts of Empire.

${ }^{9}$ For more detail, see Francis J. Gavin, Gold, Dollars, and Power: The Politics of International Monetary Relations, 1958-1971 (Chapel Hill: University of North Carolina Press, 2008), pp. 17-31, 197-202.

${ }^{10}$ Both textbook and more specialised accounts of Anglo-American relations largely omit the difficulties that ANZUS generated. See for instance: Fredrick Samuel Northedge, Descent From Power: British Foreign Policy 1945-1973 (London: George Allen and Unwin, 1974); Robert M. Hathaway, Great Britain and the United States: Special Relations Since World War II (Boston: Twayne, 1990); Robin Renwick, Fighting With Allies: America and Britain in Peace and War (Basingstoke: Macmillan, 1996); Sean Greenwood, Britain and the Cold 
War 1945-91 (Basingstoke: Macmillan, 2000). For more specialised accounts that omit this episode, see John Baylis, Anglo-American Relations Since 1939: The Enduring Alliance (Manchester: Manchester University Press, 1997); Michael F. Hopkins, Oliver Franks and the Truman Administration: Anglo-American Relations, 1948-1952 (London: Frank Cass, 2003).

${ }^{11}$ For more on British economic and military "decline" in the post-war period, see, for instance, Jim Tomlinson, "'Inventing 'decline': The falling behind of the British economy in the postwar years," Economic History Review, Vol. 49, No. 4 (1996), pp. 731-57; Jim Tomlinson, "The decline of empire and the economic 'decline' of Britain," Twentieth Century British History Vol. 14, No. 3 (2003), pp. 201-21; Catherine R. Schenk, The Decline of Sterling: Managing the Retreat of an International Currency (Cambridge: Cambridge University Press, 2010), pp. 37-80. For relations between the United Kingdom and Australia, see Tim Booth, "Imperial Self-Insufficiency Rediscovered: Britain and Australia 1945-51," Australian Economic History Review, Vol. 39, No. 1 (1999), pp. 29-51.

${ }^{12}$ Recent efforts concerning race and U.S. foreign policy include Penny Von Eschen, Race against Empire: Black Americans and Anticolonialism, 1937-1957 (Ithaca: Cornell University Press, 1997); Alexander DeConde, Ethnicity, Race and American Foreign Policy: A History (Chicago: Northeastern University Press, 1993); Thomas Borstelmann, The Cold War and the Color Line: American Race Relations in the Global Arena (Cambridge MA: Harvard University Press, 2001); Matthew Jones, After Hiroshima: The United States, Race and Nuclear Weapons in Asia, $1945-1965$ (Cambridge: Cambridge University Press, 2010), Philip E. Muehlenbeck (ed), Race, Ethnicity, Religion and the Cold War: A Global Perspective (Nashville: Vanderbilt University Press, 2012).

${ }^{13}$ The classic text on U.S. attitudes towards British imperialism and Empire remains William Roger Louis, Imperialism at Bay: The United States and the Decolonization of the British Empire, 1941-1945 (Oxford: Oxford University Press, 1987).

${ }^{14}$ Reynolds has highlighted the influence of "race" upon the creation of Australian foreign policy throughout the Cold War: David Reynolds, "Empire, Region, World: the International Context of Australian Foreign Policy since 1939," in Australian Journal of Politics and History, Vol. 51, No. 3 (2005), pp. 346-58.

15 "Policy Statement of the Department of State," 18 August 1948, in Foreign Relations of the United States 1948 (hereafter referred to as FRUS, with appropriate year and volume numbers), Vol. VI, p. 1.

${ }^{16}$ Ibid., p. 2.

${ }^{17}$ Lowe, Menzies, p. 17. On U.S.-UK-Australian relations during 1945-51, see Joseph M. Siracusa and Glen St John Barclay, "Australia, the United States, and the Cold War, 1945-51: From V-J Day to ANZUS," Diplomatic History, Vol. 5, No. 1 (1981), pp. 39-52; Christopher Waters, The Empire Fractures: Anglo-Australian Conflict in the 1940s (Melbourne: Australian Scholarly Publishing, 1995).

18 "Policy Statement of the Department of State," 18 August 1948, in FRUS 1948, Vol. VI, p. 2.

${ }^{19}$ The British pound was set at \$4.03 with the Australian pound being effectively pegged to sterling until 1967. For more detail, see David Sanders, Losing an Empire, Finding a Role: British Foreign Policy since 1945 (Basingstoke: Macmillan, 1990), pp. 200-6.

${ }^{20}$ Gavin, Gold, Dollars, and Power, pp. 17-31.

21 "Department of State, Policy Statement," 21 April 1950, in FRUS 1950, Vol. VI, pp. 189-90.

${ }^{22}$ Ibid.

${ }^{23}$ Curt Cardwell, NSC 68 and the Political Economy of the Early Cold War (Cambridge: Cambridge University Press, 2012). The authors would contend that economic motivations were not the dominate factor behind U.S. policy. On the importance U.S. decision makers attached to promoting and maintaining the Bretton Woods economic system as a part of a broader national security policy see: Melvyn P. Leffler, A Preponderance of Power: National security, The Truman Administration, and the Cold War (Stanford: Stanford University Press, 1992). A good overview on the historiography of NSC-68 can be found here: Ken Young, "Revisiting NSC 68". Journal of Cold War Studies, Vol. 15, No. 1 (2013), pp. 3-33.

${ }^{24}$ The extent of Soviet espionage is revealed within: Christopher Andrew and Vasili Mitrokhin, The Sword and the Shield: The Mitrokhin archive and the secret history of the KGB (New York: Penguin, 2000). On Stalin's atomic weapons espionage see David Holloway, Stalin and the Bomb: The Soviet Union and Atomic Energy, 1939-1956 (New Haven: Yale University Press, 1996).

${ }^{25}$ Fredrick Logevall "The Indochina wars and the Cold War, 1945-1975," in Melvyn P. Leffler and Odd Arne Westad (eds.), The Cambridge History of the Cold War, Volume II: Crisis and Détente (Cambridge: Cambridge University Press, 2010), p. 284. For a fuller account of U.S. involvement in Vietnam at this stage see Fredrick Logevall, Embers of War: The Fall of an Empire and the Making of America's Vietnam (New York: Random House, 2012), pp. 217-37.

${ }^{26}$ For claims that NSC-68 was a "global policy," see Julian E. Zelizer, Arsenal of Democracy: The Politics of National Security-From World War II to the War on Terrorism (New York: Basic Books, 2010), p. 102. On the change of attitude that was generated by the Communist victory in China upon Washington policy-makers, see 
John Lewis Gaddis, Strategies of Containment: A Critical Appraisal of American National Security Policy during the Cold War (New York: Oxford University Press, 2005), pp. 82-90.

${ }^{27}$ Thomas J. Schoenbaum, Waging War and Peace: Dean Rusk in the Truman, Kennedy and Johnson Years (New York: Simon and Schuster, 1988), p. 229.

${ }^{28}$ Zelizer, Arsenal of Democracy, p. 84.

${ }^{29}$ NSC $13 / 2$ is officially titled: "Progress Report on the Implementation of U.S. Policy toward Japan." On the implications on NSC 13/2, as well as this shift in American thinking towards Japan, see Thomas H. Etzold, "The Far East in American Strategy, 1948-1951," in Thomas Etzold (ed.), Aspects of Sino-American Relations since 1784 (New York: Orchard Books, 1978), pp. 110-16; Eiji Takemae, The Allied Occupation of Japan and its Legacy (London: Continuum, 2002), pp. 457-68.

${ }^{30}$ Michael Schaller, The American Occupation of Japan: The Origins of the Cold War in Asia (Oxford: Oxford University Press, 1985), pp. 142-69; Geoffrey Perret, Old Soldiers Never Die: The Life of Douglas MacArthur (New York: Random House, 1996), p. 535.

${ }^{31}$ In essence, a peace treaty would help to address fears from international investors that Japan was a stable place in which to invest. The Truman administration's determination to create a Japanese peace treaty is emphasised in NSC 48/2. This can be viewed in: Thomas Etzold and John Lewis Gaddis (eds.), Containment: Documents on American Policy and Strategy, 1945-1950 (New York: Columbia University Press, 1978), pp. 252-64. For a good overview of the importance of NSC 48/2 in relation to Japan, see Jones, After Hiroshima, pp. 52-6.

32 The Minister of External Affairs to the Minister for External Affairs in Australia, 27 March 1947, in Robin Kay (ed.), Documents on New Zealand External Relations: The ANZUS Pact and the Treaty of Peace with Japan (Wellington: V.R. Ward Government Printer, 1985), Vol. III, Doc. 5, pp. 12-13 (hereinafter referred to as The ANZUS Pact); The First Secretary, New Zealand Legation, Washington, to the Secretary of External Affairs, 13 May 1947 in The ANZUS Pact, Doc. 26, pp. 46-7.

${ }^{33}$ Peggy Warner and Sadao Seno, The Coffin Boats: Japanese Midget Submarine Operations in the Second World War (London: Leo Cooper, 1986), chapters 7-9.

${ }^{34}$ For an example of this line of argument: David Day, The Great Betrayal: Britain, Australia \& the Onset of the Pacific War, 1939-42 (North Ryde: Angus and Robertson, 1988).

${ }^{35}$ Lowe, Menzies, pp. 25-42; Louis, Imperialism at Bay, pp. 299-300.

${ }^{36}$ For a convincing argument about the fear of a resurgent Japan in Australian strategic thinking in this period, see Meaney, "Look Back in Fear," pp. 42-3. For examples of New Zealand concerns, see The Minister of External Affairs to the Secretary of State for Commonwealth Relations, 15 July 1947, in ANZUS PACT, Doc. 42, pp. 68-9.

${ }^{37}$ See, for instance: "Strategic Implications of the Spread of Communism in China and its Effect on South East Asia," JIC Appreciation no. 5/29 (2) final, 2 August 1949, A816/27 item 14/301/393, National Archive of Australia (Hereafter: NAA). On the distinctive lack of Cold War influence upon Australian thinking at this stage, see Lowe, Menzies, pp. 14-17; Christopher Waters, "Anglo-Australian conflict over the Cold War: HV Evatt as President of the UN General Assembly, 1948-49," Journal of Imperial and Commonwealth History, Vol. 22, No. 2 (1994), pp. 294-316.

${ }^{38}$ For examples of Australian concerns about a resurgent Japan: Meaney, “Look Back in Fear," pp. 39-41; Alan Renouf, Let Justice Be Done: The Foreign Policy of Dr HV Evatt (Brisbane: University of Queensland Press, 1983). The United States was fully aware of Australian concerns about a re-armed and reindustrialised Japan: "Policy Statement of the Department of State," 18 August 1948 in FRUS 1948, Vol. VI, pp. 3-4. For some examples of New Zealand opinion: The High Commissioner for Canada to the Secretary of Eternal Affairs, 23 July 1947, in ANZUS Pact, Doc. 49, pp. 81-3; The New Zealand Minister, Washington, to the Minister of External Affairs, 24 July 1947, in ANZUS Pact, Doc. 50, pp. 83-5.

${ }^{39}$ Memorandum by the Department of External Affairs on the General Attitude to the Japanese Settlement, 11 August 1947, in ANZUS Pact, Doc. 58, pp. 94-5.

${ }^{40}$ Reynolds, "Empire, Region, World," p. 353.

${ }^{41}$ The Statue of Westminster provided Australia and New Zealand with the right to conduct their own foreign policy independently of the United Kingdom. However, it was not until 1942 that the Australian government actually passed a law to ratify the treaty. New Zealand would ratify the treaty in 1947.

${ }^{42}$ Gerhard L. Weinberg, A World At Arms: A Global History of World War II (Cambridge: Cambridge University Press, 1994), pp. 320-1.

${ }^{43}$ On efforts by the British, Australian and New Zealand governments to react to the growing might of the United States within the Pacific, see P.G.A. Orders, Britain, Australia, New Zealand and the Challenge of the United States, 1939-46: A Study in International History (Basingstoke: PalgraveMacmillan, 2003); Christopher Baxter, The Great Power Struggle in East Asia, 1945-50 (Basingstoke: PalgraveMacmillan, 2009). 
${ }^{44}$ Memorandum of Australian Government's Observations of United Kingdom Chiefs of Staff Memorandum COS (52) 685, attached to Prime Minister to High Commissioner, 27 March 1953, A 5954, 1424/3, NAA.

45 "Policy Statement of the Department of State: United States Relations with New Zealand," 24 September 1948, in FRUS 1948, Vol. VI, p. 9.

${ }^{46}$ For overviews on Australian foreign policy: Alan Watt, The Evolution of Australian Foreign Policy, 19381965 (Cambridge: Cambridge University Press, 1967); Peter Edwards with Gregory Pemberton, Crises and Commitments: The Politics and Diplomacy of Australia's Involvement in Southeast Asian Conflicts, 1948-1965 (Sydney: Allen and Unwin, 1992). On the intelligence aspects, see Christopher Andrew, "Intelligence in the Cold War," in Melvyn Leffler and Odd Arne Westad, The Cambridge History of the Cold War: Volume II Crisis and Détente (Cambridge: Cambridge University Press, 2010), p. 418; Richard Aldrich, GCHQ (London: HarperCollins, 2010), pp. 92-5.

${ }^{47}$ Lowe, Menzies, pp. 49-60.

${ }^{48}$ Steven Hugh Lee, Outposts of Empire: Korea, Vietnam and the Origins of the Cold War in Asia, 1949-1954 (Liverpool, Liverpool University Press, 1995), p. 29.

${ }^{49}$ Percy Spender Report to Cabinet, "Pacific Defence Pact: Forthcoming Exploratory Talks with Mr John Foster Dulles," 15 February 1951, A4940, C228, NAA.

${ }^{50}$ The Secretary of External Affairs to the Official Secretary, Office of the High Commissioner for New Zealand, Canberra, 29 September 1949, ANZUS Pact, Doc. 184, p. 506.

${ }^{51}$ Schenk, The Decline of Sterling, pp. 60-8; Malcolm Chalmers, Paying for Defence: Military Spending and British Decline (London: Pluto Press, 1985), p. 41; Reynolds, Britannia Overruled, p. 169.

${ }^{52}$ Memorandum by Secretary of State for Commonwealth Relations, 2 October 1950, Box 1/9,The Patrick Gordon Walker Papers, Churchill Archive, Cambridge University (Hereafter GNWR), United Kingdom.

${ }^{53}$ Ravindra Varma, Australia and South Asia: The Crystallisation of a Relationship (New Delhi: Abhinav Publications, 2003), pp. 106-7.

${ }^{54}$ TNA: PREM 11/403 UK High Commissioner in Australia to the Commonwealth Relations Office, Tel. 221, 28 March 1953.

${ }^{55}$ Menzies to Allen, MP464/3, item 99/1/498/1, NAA; Spender to Menzies, 8 June 1950, MP464/3, item 99/1/498/1, NAA.

${ }^{56}$ Not least in the economic realm where serious differences existed. See for example the documentation contained within: TNA: T 236/2498. For Australian complaints about British economic behaviour, see Percy Spender to Robert Menzies, 14 January 1950, CRS A1838, item 532/7, NAA.

${ }_{57}^{57}$ Memorandum by Secretary of State for Commonwealth Relations, 2 October 1950, Box 1/9, GNWR.

${ }^{58}$ Alan Bullock, Ernest Bevin: Foreign Secretary, 1945-51 (London: Heinemann, 1983), pp. 655-715; John Young, Britain and European Unity, 1945-1992 (London: Macmillan, 1993), pp. 14-18; John Kent, British Imperial Strategy and the Origins of the Cold War, 1944-49 (Leicester, Leicester University Press, 1994); Stuart Croft, The End of Superpower: British Foreign Office Conceptions of a Changing World, 1945-51 (Aldershot: Ashgate, 1994).

59 TNA: FO 371/83014 Talks between Dean Rusk of the United States and M.E. Dening for the United Kingdom in Washington, July 1950.

${ }^{60}$ Ovendale, Anglo-American Relations, pp. 60-1. This type of thinking is encapsulated in the following papers created by the British Joint Chiefs of Staff and Foreign Office Planning Staff: TNA: FO 371/56832 Russian Policy and British Attitudes towards Russia, March 1946; TNA: DEFE 4/18 COS (48) $168^{\text {th }}$ Meeting, Chiefs of Staff Committee: Minutes of Meeting held on 24 November 1948.

${ }^{61}$ Marc Trachtenberg, A Constructed Peace, The Making of a European Peace Settlement, 1945-63 (Princeton: Princeton University Press, 1999), pp. 3-56.

62 "Memorandum by CIA, National Intelligence Estimate," 13 November 1951, in FRUS, 1951, Vol. I, pp. 11112.

${ }^{63}$ TNA: CAB 158/4 (Part 2) JIC 48 (48) 87 (0), Report by the Joint Intelligence Committee: Strategic Intentions of the Soviet Union Scale and Nature of Russian attacks on Certain Areas, 6 August 1948; TNA: CAB 158/4 (Part 2), JIC (48) 104 Final, Report by the Joint Intelligence Committee: Soviet Intentions and Capabilities 1949 and 1956/7, 8 November 1949; TNA: CAB 159/7 JIC (50) Chiefs of Staff Committee, Joint Intelligence Committee, "Minutes of the Twenty Second Meeting of the Committee," 24 February 1950.

64 "Memorandum by CIA, National Intelligence Estimate," 13 November 1951, in FRUS, 1951, Vol. I, pp. 111 12.

${ }^{65}$ TNA: CAB 158/7 JIC (49) 40 Final, Report by the Joint Intelligence Committee: The Implications of a Communist Success in China, 30 September 1949.

${ }^{66}$ On the Malayan Emergency, see Robert Jackson, Malayan Emergency and Indonesian Confrontation: The Commonwealth's Wars, 1948-1966 (London: Pen and Sword, 2011). 
${ }^{67}$ Statement by the Secretary of State, 18 May 1949 contained within: Dean Acheson Papers, Press Conference File, 1949-53, January-June 1949, Box 72, Harry S. Truman Presidential Library (Hereafter HSTL), Independence, Missouri, United States of America.

${ }^{68}$ Aldrich, GCHQ, p. 100; Andrew, In Defence of the Realm, pp. 386-90; Christopher Andrew, For the President's Eyes Only: Secret Intelligence and the American Presidency from Washington to Bush (London: HarperCollins, 1996), pp. 184-6.

${ }^{69}$ The literature on the Korean War is extensive. For a popular military history, see Max Hastings, The Korean War (New York: Simon and Schuster, 1988). For the most comprehensive international account, see William Stueck, The Korean War: An International History (New Jersey: Princeton University Press, 1997).

${ }^{70}$ See the full speech here: Proclamation 2914 - Proclaiming the Existence of a National Emergency, President Truman, 16 December 1950, available at: http://www.presidency.ucsb.edu/ws/?pid=13684 (Accessed 11 April 2013).

${ }^{71}$ Quote in Thomas Fleming, "The Man who saved Korea," in Robert Cowley (ed.), The Cold War: A Military History (New York: Random House, 2005), p. 106.

${ }^{72}$ Acheson, Present at the Creation, pp. 478-90.

${ }^{73}$ On the creation of the national security apparatus: Daniel Yergin, The Shattered Peace: The Origins of the Cold War and the National Security State (Boston: Houghton Mifflin, 1977). For the creation of the American intelligence community, see Aldrich, GCHQ, pp. 100-1; Andrew, For the President's Eyes Only: pp. 187-190. On the effect of the Korean War upon U.S. European policy, see Leffler, A Preponderance of Power, pp. 37490. On the impact of the Korean War upon U.S. efforts to settle a Japanese peace treaty see for example: Sebald to Acheson, 27 June 1950, in FRUS 1950, Vol. VI, pp. 1228-9; Dulles to Acheson, 19 July 1950, in FRUS 1950, Vol. VI, pp. 1243-4.

${ }^{74}$ William Gibbons, The U.S. Government and the Vietnam War: Executive and Legislative Roles and Relationships (Princeton: Princeton University Press, 1986). On the point made in the text, see Gaddis, We Now Know, pp. 26-125.

${ }^{75}$ See the documentation contained within: FRUS 1950-1954, Vol. VI, pp. 148-52; 200-1; 212-17; 222-5.

${ }^{76}$ Dulles and Dean Rusk, who was undersecretary of state for far eastern affairs at this stage of his career, were both advocates of a more comprehensive Asian security pact. The Joint Chiefs of Staff were also coming round to the idea that the U.S. should enter into limited security pacts throughout Asia: Schoenbaum, Waging War and Peace, pp. 226-9.

${ }^{77}$ Leffler, Preponderance of Power, pp. 391-3. The importance of Japan is explicitly outlined within an April 1951 National Intelligence Estimate, see "Memorandum by the Central Intelligence Agency," 20 April 1951, in FRUS, 1951, Japan, Vol. VI, p. 993.

78 "Progress report by Secretaries of State and Defense to the National Security Council, [Annex 2]," 25 September 1951, in FRUS, 1951, Vol. I, p. 83.

79 "Memorandum by the Central Intelligence Agency," 20 April 1951, in FRUS, 1951, Japan, Vol. VI, p. 994.

${ }^{80}$ On the direct linkage between the Korean War and the political transformations within Japan, see Masuda Hajimu, "Fear of World War III: Social Politics of Japan's Rearmament and Peace Movements, 1950-3," Journal of Contemporary History, Vol. 47, No. 3 (2012), pp. 551-71.

81 "Intelligence Estimate, Office of Intelligence and Research," 25 June 1950, in FRUS 1950, Vol. VII, p. 151.

${ }^{82}$ John Foster Dulles, "A Diplomat and his Faith," in Christian Century within: Correspondence between John Foster Dulles and Secretary of State Dean Acheson, March 26, 1952. Secretary of State File, Acheson Papers, Truman Library.

${ }^{83}$ For the creation of the Japanese peace treaty see Jones, After Hiroshima, pp. 116-21; John Swenson-Wright, Unequal Allies? United States Security and Alliance Diplomacy, 1945-1960 (Stanford: Stanford University Press, 2005), chapter two.

${ }^{84}$ Baxter, Great Power Struggle, p. 102.

${ }^{85}$ Ibid., p. 169.

${ }^{86}$ The Ambassador in the United Kingdom to the Secretary of State, 4 June 1951 in FRUS 1951, Vol. VI, Part 1, pp. 1105-6; The Ambassador in the United Kingdom to the Secretary of State, 8 June 1951, in Ibid., pp. 110910.

${ }^{87}$ Alec Cairncross, The British economy since 1945 (Oxford: Wiley-Blackwell, 1995, $2^{\text {nd }}$ edition), pp. 49, 79-80, 99-104; Chalmers, Paying for Defence, pp. 22, 33, 50-53. The clearest British complaint that a resurgent Japan would harm British economic interests appears in: TNA: FO 371/76208 William Strang to Ernest Bevin, 27 February 1949. See for example: Visit of Prime Minister Yoshida: South and Southeast Asian Economic Cooperation, 5 November 1954 in MCO74, Folder 8, Box 1, John Foster Dulles Papers (hereafter: JFDP).

88 "The Consultant to the Secretary (Dulles) to the Secretary of State," 4 January 1951, in FRUS, 1951, Japan, Vol. VI, p. 782. 
${ }^{89}$ See for example: "Mr John Foster Dulles, the Consultant to the Secretary, to the Supreme Commander for Allied Powers (MacArthur), "18 March 1951, in FRUS 1951, Japan, Vol. VI, p. 931.

${ }^{90}$ Lowe, Containing the Cold War in East Asia, pp. 27-9.

91 "Memorandum of Conversation by the Deputy Director of the Office of British Commonwealth and Northern European Affairs," 30 March 1951, in FRUS 1951, Japan, Vol. VI, pp. 953-4; "The Deputy to the Consultant (Allison) to the Consultant to the Secretary (Dulles)," 5 April 1951, in FRUS 1951, Japan, Vol. VI, pp. 961-4; "Memorandum of Conversation by the Deputy to the Consultant," 12 April 1951, FRUS 1951, Japan, Vol. VI, pp. 978-9.

${ }^{92}$ Dulles agreed that it would be preferable to appease the British on minor points of the Treaty so that the British government could save face. See: "Memorandum by Mr Robert A. Fearey of the Office of Northeast Asian Affairs," undated, (April 1951), in FRUS 1951, Japan, Vol. VI, pp. 980-4.

${ }^{93}$ Longer-term Australian and New Zealand complaints about U.S. policy towards Japan can be seen in: "Policy Statement of the Department of State: U.S. relations with Australia," 18 August 1948, in FRUS 1948, Vol. VI, p. 5; "Policy Statement of the Department of State: United States Relations with New Zealand," 24 September 1948, in Ibid., p. 9; Talk between Percy Spender and Dean Acheson, 18 September 1950, RG59 53/ D444, National Archives II, College Park, Maryland, United States of America (Hereafter: NAII); "The Acting High Commissioner for the United Kingdom, Wellington, to the Minister of External Affairs," 8 August 1949 in ANZUS Pact, Doc. 96, p. 271; "The First Secretary, New Zealand, Washington, to the Secretary of External Affairs," 14 September 1949, in ANZUS Pact, Doc. 102, p. 282. For Australian and New Zealand complaints about the latest developments see discussions between Dulles, Spender and Doidge: "Notes on the AustralianNew Zealand-United States Talks in Canberra," 15-17 February 1951, in ANZUS Pact, Doc. 226, pp. 593-613. Such complaints were reported to Washington: "Memorandum by the Assistant Secretary of State for Far Eastern Affairs (Rusk) to the Acting Secretary of State," 22 February 1951, in FRUS, 1951, Japan, Vol. VI, pp. 891-2.

${ }^{94}$ A point the United States well recognised. "Memorandum from Assistant Secretary of State to Secretary of State," 27 October 1950, in FRUS 1950, Vol. VI, pp. 224-5.

95 "The Secretary of State to the Secretary of Defense," 24 November 1950, in FRUS 1950, Vol. VI, p. 225.

${ }^{96}$ See the briefing material prepared for the Menzies visit here: Background Memoranda prepared in the Department of State, 24 July 1950, RG 59 743.13/7-2450, NAII; Memorandum by the Assistant Secretary of State for European Affairs, Perkins, to the Secretary of State, 27 July 1950, RG 59 743.13/7-2750, NAII; Report prepared by the Department of State on the visit of Menzies, undated, RG 59 743.13/8-750,NAII;"'The Secretary of State to the Embassy in Australia," 3 August 1950, in FRUS 1950, Vol. VI, pp. 206-7. The discussion can be followed here: "Memorandum of Conversation with President Harry S. Truman and Prime Minister Robert Menzies of Australia," 28 July 1950 in Secretary of State Files, Acheson Papers, HSTL.

${ }^{97}$ See, "Report prepared by the Department of State on the visit of Menzies; Memorandum of Conversation by the Secretary of State," 28 July 1950, RG 59 743.13/8-750, NAII; "Memorandum of Conversation by the Secretary of State," 31 July 1950, RG 59 743.13/8-750, NAII; "The Secretary of State to the Embassy in Australia, 3 August 1950," in FRUS 1950, Vol. VI, pp. 204-7.

98 "Record of a Discussion with Mr John Foster Dulles 14 October 1950, contained within: The Deputy Secretary of External Affairs to the Prime Minister," 27 October 1950, in ANZUS Pact, Doc. 140, p. 409.

99 "The Secretary of State to the Secretary of Defense," 24 November 1950, in FRUS 1950, Vol. VI, p. 225.

100 "Department of State, Policy Statement," 21 April 1950, in FRUS 1950, Vol. VI, pp. 189-90.

101 "Memorandum of Conversation by the Deputy to the Consultant (Allison)," 18 January, 1951, in FRUS 1951, Japan, Vol. VI, p. 804.

${ }^{102}$ See, for instance: Gavin, Gold, Dollars, and Power; Hubert Zimmermann, Money and Security: Troops, monetary policy, and West Germany's relations with the United States and Britain, 1950-1971 (Cambridge: Cambridge University Press, 2002), pp. 103, 107, 140, 227.

103 "United States Minutes of the First Meeting, ANZUS Council: Second Session," August 4, 1952, in FRUS 1952-54, Vol. XII, Part 1, pp. 178-83.

104 "Memorandum by the Secretary of State of a Meeting at the White House Between the President and General Eisenhower," November 18, 1952, in FRUS 1952-54, Vol. I, Part 1, pp. 22-9. For specific details of U.S. foreign economic policy up to 1950 , see "Papers relating to aspects of the foreign financial policy of the United States," in FRUS 1950, Vol. I, pp. 810-30.

${ }_{105}$ Zelizer, Arsenal of Democracy, pp. 124-36.

${ }^{106}$ See, for instance, Forsberg, America and the Japanese Miracle.

107 "Report of the Commonwealth Prime Ministers' Meeting in London," 9 January 1951 in ANZUS Pact, Doc. 148, pp. 436-7; "The Minister of External Affairs to the New Zealand Ambassador, Washington," 22 December 1950 in ANZUS Pact, Doc. 143, pp. 416-7; "The Counsellor, New Zealand Embassy, Washington, to the Secretary of External Affairs," 5 January 1951, in ANZUS Pact, Doc. 146, pp. 424-5. 
108 "Draft Letter to Mr Dulles" [From Dean Acheson], attached within, "The Secretary of State to the Secretary of Defense (Marshall)," 9 January, 1951, in FRUS, 1951, Japan, Vol. VI, p. 789.

${ }^{109}$ Further examples of where this linkage is made can be found within: "Memorandum by Mr Robert A. Fearey of the Office of Northeast Asian Affairs," undated [January 1951], in FRUS 1951, Japan, Vol. VI, p. 815; "Memorandum by the Consultant to the Secretary," 12 April 1951, in FRUS 1951, Japan, Vol. VI, p. 976. Dean Rusk gave a public speech where he made the connection between the security pact and the successful completion of the Japanese Peace Treaty known: Starke, The ANZUS Treaty Alliance, p. 34.

110 "Memorandum by the Central Intelligence Agency," 20 April 1951, in FRUS 1951, Japan, Vol. VI, p. 999.

${ }^{111}$ The New Zealand Ambassador, Washington, to the Minister of External Affairs, 19 January 1951, in ANZUS Pact, Doc. 149, pp. 438-9.

${ }^{112}$ On 7 February 1951, Prime Minister Holland reported that, "the prospects of some form of Pacific Pact are good." See: From Prime Minister for Mr Doidge contained within: "The New Zealand Ambassador, Washington, to the Minister of External Affairs," 7 February 1951 in ANZUS Pact, Doc. 214, p. 574. A day later Berendsen reported that Rusk had raised the prospect of a tripartite security pact: "From the Prime Minister for Mr Doidge" within: "The New Zealand Ambassador, Washington, to the Minister for External Affairs," 8 February 1951 in ANZUS Pact, Doc. 218, pp. 582-3.

113 "From Prime Minister to Doidge within: The New Zealand Ambassador, Washington, to the High Commissioner for New Zealand, Canberra," 9 February 1951 in ANZUS Pact, Doc. 220, p. 585.

${ }^{114}$ Memorandum of Conversation with Delegation from New Zealand, Elbert Mathews, and G. Hayden Raynor, 6 February 1951, Secretary of State Files, Memoranda of Conversations File, 1949-1953, File: February 1951, Box 68, Dean Acheson Papers, HSTL.

115 "Notes of the Australian-New Zealand-United States Talks in Canberra," 15-17 February 1951 in ANZUS PACT, Doc. 226, p. 593.

${ }^{116}$ Ibid., pp. 597-9. Quote at p. 599.

${ }^{117}$ Ibid., p. 594.

${ }^{118}$ Ibid., p. 601.

${ }^{119}$ Ibid., pp. 597-8.

${ }^{120}$ Ibid., p. 598.

${ }^{121}$ The ANZUS Treaty in full can be accessed here: http://australianpolitics.com/topics/foreign-policy/anzustreaty-text (Accessed 5 January 2014).

122 "Minutes of a Meeting of the Chiefs of Staff Committee and Officers of the Department of External Affairs," 6 February 1951, in ANZUS Pact, Doc. 209, p. 567.

${ }^{123}$ Australian and New Zealand opinion can be found here: "Notes on Discussions between the New Zealand and Australian Ministers of External Affairs," 13 February 1951, in ANZUS PACT, Doc. 224, pp. 590-1.

${ }^{124}$ Though it was accepted that the Soviet Union did not pose a "direct threat" against New Zealand: Ibid., p. 544 .

125 "The Minister of External Affairs to the New Zealand Ambassador," Washington, 9 May 1950, in ANZUS Pact, Doc. 200, p. 546.

${ }^{126}$ McGibbon, New Zealand and the Korean War, Vol. I, p. 287.

127 "Note on Defence Aspects of the Japanese Peace Settlement," 30 January 1950 in ANZUS Pact, Doc. 208, p. 558.

${ }^{128}$ The lack of consultation with NATO was especially galling for Australian and New Zealand policymakers given that they were an allied power in the Second World War. See for example: "The New Zealand Commissioner, Washington, to the Minister of External Affairs," 1 June 1951 in ANZUS Pact, Doc. 266, p. 723; "The Minister of External Affairs to the New Zealand Ambassador, Washington," 19 June 1951, in ANZUS Pact, Doc. 268, p. 727; Percy Spender to Richard Casey, 18 March 1952 attached to: B. Townsend to Mr Loveday, 9 July 1952, A10299, A15, NAA.

129 "Memorandum of Conversation," 8 February 1951, in FRUS 1951, Vol. I, p. 149.

${ }^{130}$ This point was reported to the New Zealand Prime Minister: "The New Zealand Permanent Representative to the United Nations, New York, to the Prime Minister," 18 March 1952, in ANZUS Pact, Doc. 305, p. 779. For more on the Chiefs, see Willard J. Webb, The Joint Chiefs of Staff and the Prelude to the War in Vietnam, 19541959 (London: MilitaryBookShop, 2011). On the reluctance of the Chiefs, see "NSC48/5, United States Objectives, Policies and Courses of Action in Asia," 17 May 1951, in FRUS, Vol. VI, pp. 31-63.

${ }^{131}$ Christopher Andrew, The Defence of the Realm: The Authorised History of MI5 (London: Allen Lane, 2009), pp. 369-73. On Australia's security problems and the remedies put in place to satisfy American concerns: "Memorandum of Conversation with Sir Frederick Shedden," 20 April 1949, Secretary of State File, Acheson Papers, HSTL.

132 "Notes of the Australian-New Zealand-United States Talks in Canberra," 15-17 February 1951 in ANZUS PACT, Doc. 226, p. 593. Spender argued forcefully that the creation of NATO would encourage the Soviet 
Union to look towards Asia for their global advances and Pacific nations should prepare for this eventuality. Direct cooperation with NATO was a clear ambition of Spender: David Lowe, Australia between Empires: The Life of Percy Spender (London: Chatto and Windus, 2010), p. 125.

${ }^{133}$ Securing a Japanese peace settlement is of clear significance throughout: "Memorandum by the Assistant Secretary of State for Far Eastern Affairs (Rusk) to the Acting Secretary of State," 22 February 1951, in FRUS 1951, Japan, Vol. VI, p. 894. On U.S. intelligence assessments of the Soviet Union's intentions in relation to Asia and Japan, see Acheson's letter to President Truman: The Secretary of Defense (Marshall) to the Secretary of State, 20 April 1951, in FRUS 1951, Japan, Vol. VI, p. 1001. For clear demonstrations that Japan had become the key state for opposing Communism in Asia: "The Ambassador in the Philippines to the Secretary of State," 15 March 1951, in FRUS, 1951, Japan, Vol. VI, pp. 926-8.

${ }^{134}$ See the original Australian proposals within: "Memorandum of Conversation between F. Officer, P. Spender for Australia and J. Hickerson and W. Allen for the United States, New York," 12 October 1950, RG 59 790.5/10-1250, NAII. New Zealand policy-makers had also intended for a "regional association" which would comprise the UK, United States, Australia and "only such other countries having interests in the Pacific area." See: "The Prime Minister to the High Commissioner for the United Kingdom," 6 July 1948, in ANZUS Pact, Doc. 163, p. 477. In May 1950, New Zealand's foreign minister, Frederick Doidge had publically stated that a Pacific Security Pact would have to contain "powerful nations" like the United States, United Kingdom, Canada and India. See: "Statement by the Minister of External Affairs," 9 May 1950, in ANZUS Pact, Doc. 201, p. 547.

${ }^{135}$ One British official reported to London that when Eisenhower took office, the Middle East dominated conversation and appeared to be the only subject of interest for the new president. See: Sir Roger Makins to Anthony Eden, 4 March 1953, in Avon Papers, FO 800/759, Con/53/33, Cadbury Research Library, Birmingham University, United Kingdom. The Australians had only entered into planning level discussions with the United Kingdom about the despatch of forces to the Middle East in the event of a war. Menzies had sought to expand Australian forces, however, in order to ensure that enough resources would remain in Australia for home defence in the event of a general war. New Zealand had gone a lot further than their antipodean neighbour and the New Zealand Prime Minister, Peter Fraser, had agreed to despatch forces to the Middle East, which the United Kingdom believed was necessary. In real terms, this would have meant the vast majority of the New Zealand army. On this point, see David Devereaux, "Britain, the Commonwealth and the Defence of the Middle East,” Journal of Contemporary History, Vol. 24, No. 2 (1989), p. 332.

${ }^{136}$ This point is clearly emphasised within Lowe, Menzies. For quote, see Lowe, Percy Spender, pp. 124-5.

137 "The New Zealand Ambassador, Washington, to the Minister of External Affairs," 14 March 1950, in ANZUS Pact, Doc. 198, pp. 522-536. Quotes at p. 523, 524.

${ }^{138}$ Report by the Joint Planning Committee: "The Defence of the Pacific-Strategic Background and Examination of the Military Requirements for A Pacific Defence Pact": The Assistant Secretary, Chiefs of Staff Committee to the Secretary of External Affairs, 28 April 1950, in ANZUS PACT, p. 538.

${ }^{139}$ Lowe, Menzies, p. 26; "Department of State, Policy Statement," 21 April 1950, in FRUS 1950, Vol. VI, pp. 189-90. On U.S. efforts to bring down the system of imperial preference during World War II, and British resistance, see Louis, Imperialism at Bay, p. 42; Richard Toye, "The Attlee Government, the Imperial Preference System and the Creation of the Gatt," The English Historical Review, Vol. 118, No. 478 (2003), pp. 912-939.

140 "Department of State, Policy Statement: Australia," 21 April 1950, in FRUS, 1950, Vol. VI, p. 193.

${ }^{141}$ Ibid.

142 "Notes of a Cabinet Discussion," 22 March 1951, in ANZUS Pact, Doc. 240, p. 673.

${ }^{143}$ Leffler, Preponderance of Power, p. 14.

${ }^{144}$ Spender suggested that he would be willing to accept Philippine membership but a tripartite pact was preferable: "Notes of the Australian-New Zealand-United States Talks in Canberra," 15-17 February 1951, in ANZUS PACT, Doc. 226, p. 609. On the obvious discomfort that Philippine membership created in Australian and New Zealand policy-making circles see: "The Minister of External Affairs to the New Zealand Ambassador, Washington," 21 February 1951, in ANZUS Pact, Doc. 230, p. 624; "Notes on Discussions held in the Department of External Affairs," 19 March 1951, in ANZUS Pact, Doc. 237, pp. 662-3.

${ }^{145}$ Meg Gurry, "Leadership and Bilateral Relations: Menzies and Nehru, Australia and India, 1949-1964," Pacific Affairs, Vol. 65, No. 4 (1992-93), pp. 510-526.

${ }^{146}$ See for example: Report by the Joint Planning Committee: "The Defence of the Pacific-Strategic Background and Examination of the Military Requirements for A Pacific Defence Pact": The Assistant Secretary, Chiefs of Staff Committee to the Secretary of External Affairs, 28 April 1950, in ANZUS PACT, Doc. 199, p. 538-43.

147 "Notes of Discussions held in the Department of External Affairs," 19 March 1951, in ANZUS Pact, Doc. 237 , p. 663. 
${ }^{148}$ As Dulles made clear in his discussions in Canberra: "Notes of the Australian-New Zealand-United States Talks in Canberra," 15-17 February 1951, in ANZUS PACT, Doc. 226, p. 602; "The Assistant Secretary, Chiefs of Staff Committee to the Secretary of External Affairs," 28 April 1950, in ANZUS Pact, Doc. 199, p. 537.

${ }^{149}$ See the following paper that articulates UK strategic thinking: Documents on British Policy Overseas: Korea 1950-51 (London: Her Majesty's Stationary Office, 1991), $2^{\text {nd }}$ Series, Vol. IV, pp. 411-31.

${ }^{150}$ Quote within: "The High Commissioner for the United Kingdom to the Acting Secretary of External Affairs," 2 February 1951, in ANZUS Pact, Doc. 210, p. 570.

${ }^{151}$ A.W. Martin, Robert Menzies: A Life Volume II: 1944-1978 (Melbourne: Melbourne University Press, 1999), p. 168. Quote in: "Note of a Cabinet Discussion," 22 March 1951, in ANZUS Pact, Doc. 240, p. 674.

152 "Notes of the Australian-New Zealand-United States Talks in Canberra," 15-17 February 1951, in ANZUS $P A C T$, Doc. 226, p. 604.

${ }^{153}$ For Holland from Menzies, "The Minister for External Affairs in Australia to the Minister of External Affairs," 16 March 1951, in ANZUS Pact, Doc. 236, pp. 660-1.

154 "The Acting Secretary of State to the Secretary of Defense (Marshall)," 1 March 1951, in FRUS 1951, Japan, Vol. VI, p. 898; The Secretary of State to the Secretary of Defense (Marshall), 9 January, 1951, in FRUS 1951, Japan, Vol. VI, p. 789; "Memorandum by Mr Robert A. Fearey of the Office of Northeast Asian Affairs," undated [January 1951], in FRUS 1951, Japan, Vol. VI, p. 815.

155 "The Ambassador in the United Kingdom (Gifford) to the Secretary of State," 26 February 1951, in FRUS 1951, Japan, Vol. VI, pp. 898-7; "Memorandum of Conversation by the Second Secretary of the Embassy in the United Kingdom," 21 March 1951, in FRUS 1951, Japan, Vol. VI, pp. 936-9. It is interesting to note that the majority of British complaints levelled at the U.S. draft of the Japanese peace treaty were that it did not adequately account for the likely negative economic impact it would have upon the United Kingdom. See for example: "The British Embassy to the Department of State," 12 March 1951, in FRUS, 1951, Japan, Vol. VI, pp. 909-13.

156 "Mr John Foster Dulles, the Consultant to the Secretary, to the Supreme Commander for Allied Powers (MacArthur)," 18 March 1951, in FRUS 1951, Japan, Vol. VI, p. 931.

157 "Memorandum of Conversation, by the Deputy to the Consultant (Allison)," 5 April 1951, FRUS 1951, Japan, Vol. VI, p. 964; "Memorandum of meeting with Ambassador Sir Oliver Franks of Great Britain," 2 April 1951, Secretary of State Files, Acheson Papers, HSTL.

${ }^{158}$ Lowe, Menzies, p. 79.

${ }^{159}$ For those that downplay Anglo-American difficulties over the creation of ANZUS, or suggest that the whole episode is a model of "empire by invitation": John Williams, "ANZUS: A Blow to Britain's Self-Esteem," Review of International Studies, Vol. 13, No. 4 (October 1987), pp. 245-7; Lee, Outposts of Empire, pp. 1-18. For "self-esteem" arguments, see Williams, British Self Esteem, pp. 245-7; Steve Marsh, "Anglo-American Relations 1950-1: Three Strikes for British Prestige," Diplomacy and Statecraft, Vol. 23, No. 2 (2012), pp. 304330.

${ }^{160}$ Matthew Jones, "The Radford Bombshell: Anglo-Australian-U.S. relations: Nuclear Weapons and the Defence of South East Asia, 1954-57," Journal of Strategic Studies, Vol. 27, No. 4 (2004), p. 638; British Commonwealth Defence Discussions, September 1953, A1209 1957/4652 NAA. Material on this can be followed within: NAA: A5954 1453/5. See especially: Ibid: Defence Committee Agendum, 8 November 1954; Ibid., ANZAM Arrangements-Query of the New Zealand Chiefs of Staff, 4 October 1954; Ibid., Minute by the Defence Committee, 18 March 1954.

${ }^{161}$ The Cabinet discussion on ANZUS can be followed in: TNA: CAB 129/44 CP(51)64, "Pacific Defence," 27 February 1951.

${ }^{162}$ For complaints made to the U.S, see: "Editorial Note of Meeting held on 29 January 1951," in FRUS 1951, Japan, Vol. VI, p. 826; "Memorandum by Allison of conversation on the Japanese Peace Settlement between Franks and Graves of the British Embassy with Dulles, Magruder, Babcock and Allison on January 12 1951," RG 59 694.001/1-1251, NAII; "Memorandum by Allison of conversation between Dulles and Gascoigne," February 2 1951, RG 59, 694.001, NAII. For internal grumbling within the British foreign policy making establishment see, for example, TNA: DO 35/2927 Gascoigne to Foreign Office, 7 February 1951; "The High Commissioner for the United Kingdom to the Acting Secretary of External Affairs," 2 February 1951 in ANZUS Pact, Doc. 210, p. 570. The New Zealand High Commissioner to Canberra reported increasing UK pressure upon the Australians about the nature of a Pacific Defence Pact. See: "The High Commissioner for New Zealand, Canberra, to the Minister of External Affairs," 5 February 1951, in ANZUS PACT, Doc. 212, p. 572.

163 "Editorial Note," 8 May 1951, in FRUS 1951, Japan, Vol. VI, p. 1040. On the importance that British policymakers attached to the appearance of being a "world power" see Christopher Baxter, "The Foreign Office and Post-war Planning for East Asia, 1944-45," Contemporary British History, Vol. 21, No. 2 (2007), pp. 149-72.

164 "Notes on conversations between Dulles, Spender and Doidge by R. Fearey," 16 and 17 February 1951, RG 59, 54/423, NAII. 
${ }^{165}$ Booth, "Imperial Self-Insufficiency Rediscovered," pp. 29-51

${ }^{166}$ Schenk, Decline of Sterling, pp. 122-3.

${ }^{167}$ During the actual Canberra talks, both Spender and Doidge had suggested that British membership of ANZUS in the future "should be kept in mind." See: "Notes of the Australian-New Zealand-United States Talks in Canberra," 15-17 February 1951 in ANZUS PACT, Doc. 226, p. 607.

${ }_{168}$ On U.S.-UK disagreements about the recognition of Mao's China, see Lanxin Xiang, "The Recognition Controversy: Anglo-American Relations in China, 1949," Journal of Contemporary History, Vol. 27, No. 2 (1992), pp. 319-43. For more on Anglo-American security cooperation see Richard Aldrich, The Hidden Hand: Britain, America and Cold War Secret Intelligence (London: John Murray, 2001), passim.

${ }^{169}$ For works which raise the issue of race and the ANZUS agreement see: Beisner, Dean Acheson, p. 502; Travis J. Hardy, "The Consanguinity of Ideas: Race and Anti-communism in the U.S.-Australian Relationship, 1933-1953," The University of Tennessee, PhD Dissertation; Srdjan Vucetic, The Anglosphere: A Genealogy of a Racialized Identity in International Relations (Stanford: Stanford University Press, 2011), pp. 54-73. None of these works demonstrates that U.S. policy-makers utilized the issue of race to obscure other motivations.

${ }^{170}$ On U.S.-Indian difficulties, see McMahon, Cold War on the Periphery, pp. 82-4.

${ }^{171}$ Reginald Horsman, Race and Manifest Destiny: The Origins of American Racial Anglo-Saxonism (Cambridge, MA: Harvard University Press, 1986); Thomas C. Holt, "Marking: Race, Race-Making, and the Writing of History," The American Historical Review, Vol. 100, No. 1 (1995), pp. 1-20; Joseph Tilden Rhea, Race Pride and the American Identity (Cambridge, MA: Harvard University Press, 2001).

${ }^{172}$ John W. Dower, War Without Mercy: Race and Power in the Pacific War (New York: Pantheon, 1987); Baxter, The Great Power Struggle; Jones, After Hiroshima.

${ }^{173}$ Later in the year, Dulles made this same point explicit in one memorandum to Dean Rusk. See: "Dulles Memorandum for Rusk," 22 October 1951, in FRUS 1951, Japan, Vol. VI, pp. 1381-2. Also see: Roger Buckley, U.S.-Japan Alliance Diplomacy, 1945-1990 (Cambridge: Cambridge University Press, 1992), pp. 1243.

174 "The Minister of External Affairs to the High Commissioner for the United Kingdom," 12 March 1951, in ANZUS Pact, Doc. 234, p. 657.

${ }^{175}$ For instance, Dulles warned his British counterparts in 1951 that the U.S. had to ensure that its immigration laws did not continue to treat the Japanese as an "inferior people," and that the "policies of the United States, Australia, and New Zealand present a problem" in this regard. See: "Memorandum of Conversation by the Special Assistant to the Consultant (Allison)," 12 January, 1951, in FRUS 1951, Japan, Vol. VI, p. 794.

${ }^{176}$ Such policies were slowly being dismantled at the time. Signature of the Colombo Plan, for instance, meant that Asian students could now study in Australia, albeit in limited numbers. Nevertheless, strict immigration controls against non-white people persisted. Only in 1964 were immigration controls against non-white Europeans more fully relaxed. In New Zealand, immigration laws were relaxed in 1952 to account for the fact that New Zealand serviceman stationed in Japan were marrying Japanese women. See Gwenda Tavan, The Long, Slow Death of White Australia (London: Scribe publishing, 2005). On Australia's changing relationship with Asia, see Neville Meaney, "The End of 'White Australia' and Australia's Changing Perceptions of Asia, 1945-1990,” Australian Journal of International Affairs, Vol. 49, No. 20 (1995), pp. 171-189.

${ }^{177}$ As suggested within: Andrew J. Rotter, "Christians, Muslims, and Hindus: Religion and U.S.-South Asian Relations, 1947-1954,” Diplomatic History, Vol. 24, No. 4 (2000), p. 594.

${ }_{178}$ Zelizer, Arsenal of Democracy, pp. 126-34.

${ }^{179}$ John Prados, Vietnam: The History of an Unwinnable War, 1945-1975 (Lawrence: University Press of Kansas, 2009), pp. 24-54.

180 "Memorandum for the Secretary of Defense," 17 April 1951, in FRUS 1951, Japan, Vol. VI, p. 992.

${ }^{181}$ Peter Hennessy, The Prime Minister: The Office and its Holders since 1945 (London: Penguin, 1998), pp. 178-206.

${ }^{182}$ David Day, Reluctant Nation: Australia and the Allied Defeat of Japan (Oxford: Oxford University Press, 1995).

${ }^{183}$ David Reynolds, The Creation of the Anglo-American Alliance 1937-41: A Study in Competitive Cooperation (London: Europa Publishing, 1981), pp. 284-5; Peter Hennessy, Never Again: Britain 1945-1951 (London: Vintage, 1993), p. 365.

${ }^{184}$ Kathleen Burk, Old World, New World: The Story of Britain and America (Boston: Little, Brown and Company, 2009), pp. 595-6; Klaus Larres, Churchill's Cold War: The Politics of Personal Diplomacy (New Haven: Yale University Press, 2001), pp. 156-64. For an example of Churchill's concerns: WSC [Churchill] to Foreign Secretary, 16 November 1951, in Avon Papers, FO 800/780, M/53/51, Cadbury Research Library, Birmingham University, UK.

${ }^{185}$ For British efforts with their American counterparts: TNA: FO 371101239 "From Washington to the Foreign Office," Telegram 906, 2 September 1952; TNA: PREM 11/403 "From Washington to Foreign Office," 
5 September 1952; TNA: PREM 11/404 "From Washington to Foreign Office," 9 September 1953; TNA: PREM 11/404 "From Foreign Office to Washington," 7 September 1953. For British pressure applied to Australian and New Zealand representatives: TNA: PREM 11/404 H.C. to the Prime Minister, 6 October 1953, attached to "Note for the Record"; TNA: PREM 11/404 "From UK High Commissioner in Australia to Commonwealth Relations Office," 28 September 1953; TNA: PREM 11/404 "Far East Gen Anzus and Anzam," British Embassy to Lord Salisbury, 15 September 1953; TNA: PREM 11/404 "From Foreign Office to Washington," 7 September 1953; TNA: PREM 11/404 "Pacific Defence: Minutes of a Meeting held at 10 Downing Street," 10 June 1953.

186 TNA: PREM 11/403 "UK High Commissioner in Australia to the Commonwealth Relations Office," Telegram 221, 28 March 1953.

${ }^{187}$ TNA: PREM 11/403 "Outward Telegram from Commonwealth Relations Office to UK High Commissioner in Australia and UK High Commissioner in New Zealand," Telegram 43, 14 January, 1953; NAA: A 5954, 1424/3, "Memorandum of Australian Government's Observations of United Kingdom Chiefs of Staff Memorandum COS (52) 685," attached to Prime Minister to High Commissioner, 27 March 1953; NAA: A5954, 1424,1, "For Spender from Casey," 12 February 1953.

188 "The Prime Minister to the New Zealand Ambassador, Washington," 15 April 1952, in ANZUS Pact, Doc. 309. p. 785.

${ }^{189}$ Menzies position is detailed throughout: NAA: A 5954, 1424/3, "Memorandum of Australian Government's Observations of United Kingdom Chiefs of Staff Memorandum COS (52) 685," attached to Prime Minister to High Commissioner, 27 March 1953.

${ }^{190}$ For detailed documentation on ANZAM planning: NAA: A5954, 1626/4, "Strategic Planning in relation to Co-operation in British Commonwealth Defence," attached to Minute by Defence Committee at Meeting Held on Thursday, 8 June 1950. For Australian thinking that it was essential to avoid replicating planning within ANZAM and ANZUS see: NAA: A 5954, 1424/3, "Memorandum of Australian Government's Observations of United Kingdom Chiefs of Staff Memorandum COS (52) 685," attached to Prime Minister to High Commissioner, 27 March 1953.

${ }^{191}$ Acheson, Present at the Creation, pp. 686-688.

${ }^{192}$ Following the discussions within: "U.S. minutes of First ANZUS Council, First Session," 4 August 1952, in FRUS 1952-1954, Vol. 12, part. 1, pp. 172-178; Ibid., pp. 194-201; Ibid., pp. 242-256.

193 "From Foreign Office to Washington," 4 June 1952, in Avon Papers, FO 800/750, Co/52/12, Cadbury Research Library, Birmingham University, United Kingdom. For later examples of Australian concern see: NAA: A 5954, 1680/2, P.A. McBride to the Prime Minister, 11 May 1953; NAA: A 5954, 1680/2, "United Kingdom attitude to ANZUS" attached to P.A. McBride to the Prime Minister, 11 May 1953.

${ }^{194}$ TNA: DO 35/5967 MV (52) "Minutes of the $5^{\text {th }}$ Meeting," 3 June 1952.

${ }^{195}$ TNA: FO 371101239 WSC [Churchill] to the Foreign Secretary [Eden] 30 August 1952.

${ }^{196}$ TNA: PREM 11/403 Salisbury to the Prime Minister, 2 October 1952; TNA: PREM 11/403 Lord Salisbury to Anthony Eden, 25 September 1952.

${ }^{197}$ This interpretation differs with the following: Lowe, Percy Spender, p. 136; Steve Marsh, "Three Strikes for British Prestige," pp. 304-330.

${ }^{198}$ TNA: PREM 11/403 "Statements indicating the attitude of the Australian, New Zealand and United States Governments," attached to J.W. Morrison to D.B. Pitblado, 21 November 1952.

199 "Department of State, Policy Statement," 21 April 1950, in FRUS 1950, Vol. VI, pp. 189-90; "Memorandum for the Secretary of Defense," 17 April 1951, in FRUS 1951, Japan, Vol. VI, p. 992. On American distaste of West European colonialism more generally and the concern that it would hurt their efforts in containing the Soviet Union, see Odd Arne Westad, The Global Cold War: Third World Interventions and the Making of our Times (Cambridge: Cambridge University Press, 2006), pp. 109-111.

${ }^{200}$ TNA: PREM 11/404 COS (52) 684, "Chiefs of Staff Committee: Future of Anzam," 17 December 1952.

${ }^{201}$ TNA: PREM 11/403 Norman Brook to the Prime Minister, 26 September 1952.

${ }^{202}$ For example of such thinking see: TNA: PREM 11/403 Norman Brook to the Prime Minister, 26 September 1952; TNA: PREM 11/403 “Text of a Personal Message from Mr Casey to Mr Eden," 12 September 1952. TNA: PREM 11/403 "Inward Telegram to Commonwealth Relations Office from UK High Commissioner in New Zealand," No. 549, 20 September 1952. TNA: PREM 11/403 Norman Brook to the Prime Minister, 26 September 1952; TNA: PREM 11/403 Salisbury to the Prime Minister, 2 October 1952.

${ }^{203}$ Such was Churchill and Eden's dislike of Dulles that Eden is alleged to have made a personal plea to Eisenhower not to appoint him as Secretary of State. Churchill's first meeting with Dulles as Secretary of State went so poorly that Churchill in a fit of pique declared that he would have nothing further to do with him. Given Dulles' position as Secretary of State, this was evidently going to be difficult to accomplish! On this point, see D.R. Thorpe, Eden: The Life and Times of Anthony Eden, First Earl of Avon, 1897-1977 (London: Chatto and 
Windus, 2003), pp. 381-3; John Colville, The Fringes of Power: Downing Street Diaries: Volume 2, 1941-April 1955 (London: Hodder and Stoughton, 1985), p. 321.

${ }^{204}$ TNA: PREM 11/403 "From New York to the Foreign Office," 6 January, 1953; Roger Makins to Anthony Eden, 9 January, 1953, in Avon Papers, AP 20/16/23, Cadbury Research Library, Birmingham University, United Kingdom.

${ }^{205}$ TNA: PREM 11/404 Far East Gen Anzus and Anzam, British Embassy to Lord Salisbury, 15 September 1953; TNA: PREM 11/404 H.C. to the Prime Minister, 6 October 1953, attached to "Note for the Record."

${ }^{206}$ Churchill's thinking about the Pacific Security Pact is captured well within: Churchill to Eden, 8 May 1953, in Churchill Papers, Churchill College, Cambridge University, United Kingdom.

${ }^{207}$ NAA: A10299, A15, Spender to Menzies, 29 May 1953, attached within: Spender to Casey, 29 May 1953. For further Australian and New Zealand discussions on British proposals see: NAA: A10299, A15, Clifton Webb to Richard Casey, 27 April 1953; NAA: A10299, A15, Richard Casey to Clifton Webb, 1 April 1953; NAA: A5954, 1425/7, "Memorandum: The United Kingdom on ANZUS and ANZAM," October 1953.

${ }^{208}$ On the Eisenhower New Look strategy, see Robert R. Bowie and Richard H. Immerman, Waging Peace: How Eisenhower Shaped an Enduring Cold War Strategy, (Oxford: Oxford University Press, 1997); Campbell Craig, Destroying the Village: Eisenhower and Thermonuclear War (New York: Columbia University Press, 1998).

${ }^{209}$ Jones, After Hiroshima, pp. 289-317; Panagiotis Dimitrakis, Failed Alliances of the Cold War: Britain's Strategy and Ambitions in Asia and the Middle East (London: I.B. Tauris, 2012), pp. 12-19.

${ }^{210}$ TNA: PREM 11/404 "Pacific Defence: Minutes of a Meeting held at 10 Downing Street," 10 June 1953.

${ }^{211}$ Ibid.

${ }^{212}$ NAA: A10299, A15, Spender to Menzies, 29 May 1953 attached within: Spender to Casey, 29 May 1953.

${ }^{213}$ Jones, "Radford Bombshell," pp. 640-3.

${ }^{214}$ TNA: PREM 11/404 Sir Robert Menzies to Winston Churchill, 25 June 1953.

${ }^{215}$ Ibid.

${ }^{216}$ TNA: PREM 11/404 "Pacific Defence: Minutes of a Meeting held at 10 Downing Street," 10 June 1953.

${ }^{217}$ F. L. W. Wood, "The Anzac Dilemma," International Affairs, Vol. 29, No. 2 (1953), pp. 184-192; McIntyre, Background to the Anzus Pact, p. 396.

${ }^{218}$ Thus supporting revisionist claims about the "independence" inherent in Australian foreign policy. For a good discussion, see David Martin Jones and Mike Lawrence Smith, "Misreading Menzies and Whitlam: Reassessing the Ideological Construction of Australian Foreign Policy," in The Round Table: The Commonwealth Journal of International Affairs, Vol. 89, No. 355 (2000), pp. 387-406.

${ }^{219}$ TNA: PREM 11/404 "From the Foreign Office to Washington," 5 September 1953.

${ }^{220}$ Churchill was not unique in this regard. Successive British prime ministers would continue to overestimate their influence in negotiations with the United States in the coming decades, on a wide variety of issues. See, for instance: Nigel Ashton, Eisenhower, Macmillan and the Problem of Nasser: Anglo-American Relations and Arab Nationalism, 1955-59 (Basingstoke: Macmillan. 1996); David James Gill, Britain and the Bomb: Nuclear diplomacy, 1964-1970 (Stanford, CA: Sanford University Press, 2014); Tore T. Peterson, Decline of the AngloAmerican Middle East, 1961-1969: A Willing Retreat (Sussex: Sussex Academic Press, 2005); Thomas Robb, A Strained Partnership? US-UK Relations in the Era of Detente, 1969-77 (Manchester: Manchester University Press, 2013).

${ }^{221}$ TNA: PREM 11/404 H.C. to the Prime Minister, 6 October 1953, attached to "Note for the Record."

222 TNA: PREM 11/404 "Far East Gen Anzus and Anzam, British Embassy to Lord Salisbury," 15 September 1953.

${ }^{223}$ Marc Trachtenberg, The Cold War and After: History, Theory, and the Logic of International Politics (Princeton, New Jersey: Princeton University Press, 2012), pp. 137-41.

${ }^{224}$ TNA: PREM 11/404 "Far East Department to Commonwealth Relations Office," undated [October 1953]. 